Illinois State University

ISU ReD: Research and eData

Theses and Dissertations

$11-4-2019$

\title{
The Tragedy of Theresa Sturla: Murder, Insanity, and Womanhood on Trial in Nineteenth-Century Chicago
}

Jake Engelman

Illinois State University, jfengel@ilstu.edu

Follow this and additional works at: https://ir.library.illinoisstate.edu/etd

Part of the History Commons

\section{Recommended Citation}

Engelman, Jake, "The Tragedy of Theresa Sturla: Murder, Insanity, and Womanhood on Trial in NineteenthCentury Chicago" (2019). Theses and Dissertations. 1183.

https://ir.library.illinoisstate.edu/etd/1183

This Thesis is brought to you for free and open access by ISU ReD: Research and eData. It has been accepted for inclusion in Theses and Dissertations by an authorized administrator of ISU ReD: Research and eData. For more information, please contact ISUReD@ilstu.edu. 


\section{THE TRAGEDY OF THERESA STURLA: MURDER, INSANITY, AND WOMANHOOD ON TRIAL IN NINETEENTH-CENTURY CHICAGO}

\section{JAKE ENGELMAN}

97 Pages

On the morning of July 10,1882, a young prostitute named Theresa Sturla murdered her lover, Charles Stiles, on the sixth floor of the Palmer House in Chicago. During her trial four months later, Sturla's attorney employed a dual argument of self-defense and insanity. He claimed that his client suffered from dysmenorrhea, or painful menstruation, and that she had gone temporarily insane at the time of the murder due to her defective reproductive system. According to the defense, Stiles' abuse toward his mistress had exacerbated the disease and her only solution was to respond with violence. After a month-long trial, Sturla received a verdict of manslaughter and a one-year prison sentence. The murder and subsequent trial was a media sensation and ultimately came to embody a crisis of class and morals that was brewing in Chicago on the eve of the Progressive Era. Sturla's story reveals that it was possible for a fallen woman to slay an abusive lover and, with the help of a skilled defense attorney, manipulate common notions of woman's nature in order to garner sympathy from a male jury. The jury's verdict and the opinions expressed in the Chicago media indicated that the majority of the public had faith that middle-class principles and Christian morality would prevail. The tragedy of Theresa Sturla also demonstrates the relative plasticity of the Victorian ideal of true womanhood, showing that upward social mobility was not out of reach for a "fallen woman." However, the road to respectability for a woman like Sturla was paved in the blood of her 
abuser. By using this case as a lens, we might better understand the connections between womanhood, female sexuality, violence, and perceptions of insanity and morality in nineteenthcentury America.

KEYWORDS: Chicago; murder; insanity; crime; criminality; 19th-century; Victorian-era; women; gender; violence; sexuality 
THE TRAGEDY OF THERESA STURLA: MURDER, INSANITY, AND WOMANHOOD ON TRIAL IN NINETEENTH-CENTURY CHICAGO

JAKE ENGELMAN

A Thesis Submitted in Partial Fulfillment of the Requirements for the Degree of

MASTER OF SCIENCE

Department of History

ILLINOIS STATE UNIVERSITY 
C 2019 Jake Engelman 
THE TRAGEDY OF THERESA STURLA: MURDER, INSANITY, AND WOMANHOOD ON TRIAL IN NINETEENTH-CENTURY CHICAGO

JAKE ENGELMAN

COMMITTEE MEMBERS:

Amy Wood, Chair

Richard Hughes 


\section{ACKNOWLEDGMENTS}

First and foremost, I would like to thank Dr. Amy Wood for her expertise and guidance throughout this project. I could not have asked for a better mentor and advisor to guide me through this thesis and graduate school in general. I consider myself extremely fortunate to have had the opportunity to work with such an esteemed scholar whose academic interests align so closely with my own. I would also like to thank Dr. Richard Hughes for helping me get this project off the ground nearly a year ago in the form of my History 497 paper.

I would like to extend my gratitude to the exceptional ISU History Department faculty, and especially the professors with whom I have had the pleasure of working directly, including Professor Mary Hollywood, Dr. Katrin Paehler, Dr. Stewart Winger, Dr. Ron Gifford, Dr. Andrew Hartman, and Dr. John Reda. I would also like to thank my fellow graduate students, Taylor Hagerdorn and Stephanie Collier, for contributing valuable feedback throughout the process.

Lastly, thank you to my family for your constant support. To my very dear friend Spencer, thank you for serving as my spirit guide for the last two years and encouraging me to attend graduate school in the first place. Finally, thank you to my partner, Olga, for your unending support and love through this process. You not only helped me get through my most difficult and stressful moments, but you have also provided invaluable intellectual insight that made the outcome of this project better than I could have hoped for. 


\section{CONTENTS}

Page

ACKNOWLEDGMENTS

INTRODUCTION: “THIS IS HOW I CAME TO KILL HIM” 1

CHAPTER I: “A WANTON'S REVENGE” 23

CHAPTER II: “THE STORY OF HER SUFFERINGS”

CHAPTER III: “GO THOU AND SIN NO MORE”

$\begin{array}{ll}\text { CONCLUSION } & 85\end{array}$

$\begin{array}{lr}\text { BIBLIOGRAPHY } & 89\end{array}$ 


\section{INTRODUCTION: "THIS IS HOW I CAME TO KILL HIM"}

On a summer evening in 1882, a caller at the Chicago Board of Trade named Charles Stiles hired a horse and buggy from a stable on Wabash Avenue. He proceeded to pick up his mistress, Theresa Sturla, and the couple drove to Downing's roadhouse on the city's north side. Spending several hours drinking, dining, and playfully teasing each other, Stiles eventually told his lover that he required $\$ 500$ in order to settle some of his gambling debts, but Sturla repeatedly told him that she did not have the money. Stiles angrily grabbed her by the throat and threatened her life if she did not somehow produce what he needed. After the violent exchange Stiles ordered the horses and abandoned Theresa at the restaurant, leaving her to walk several miles home in a thunderstorm. ${ }^{1}$ Early the following morning, on July 10, 1882, a boarder on the sixth floor of Chicago's famous Palmer House was awoken by Stiles' voice crying, “Murder! Murder!" By seven o'clock Stiles lay dead in the open doorway of room 661, fatally wounded by a gunshot to the chest. Witnesses later testified that just after Stiles died, Sturla sat bent over his corpse brushing his hair back and kissing his face, saying, "I told him I would do it, and I have done it. I have done it and I am glad of it; let the law take its course, and I don't care if I swing for it."2

Having only observed the aftermath of the murder, none of the boarders on the sixth floor actually witnessed the quarrel that preceded Stiles' death, making Sturla the only living person who knew the truth of what happened in room 661. After police questioning, reporters from the Chicago Tribune, Chicago Times, and Daily Inter Ocean immediately interviewed Chicago's newest murderess. "This is how I came to kill him," she said as she began her story for the Times. Following the incident at Downing's, Sturla "determined then never to have any more to

\footnotetext{
${ }^{1}$ O.E. Turner, Sturla-Stiles Tragedy (Chicago: O.E. Hammond, 1883), 166.

${ }^{2}$ Turner, Sturla-Stiles Tragedy, 101.
} 
do with him" and claimed that she went to the Palmer House with the intention of saying goodbye to Stiles for the last time. When she asked for "just one kiss for the old love's sake," Stiles threatened to kill her, pushed her to the ground and kicked her in the side. When she stood up, he grabbed her neck - “a favorite trick of his.” In his grasp, Theresa pulled out her pistol and warned him that it might go off. Before she knew it the shot was fired. In her multiple recitations of the story, Sturla maintained that she had no memory of the time between when the first shot was fired and when she was taken to Cook County jail. She remained in custody for the next four months awaiting her trial where she faced capital punishment. ${ }^{3}$

The murder could seemingly be justified as a case of self-defense, which was indeed the first piece of the two-pronged defense that Sturla's attorney employed during the trial. The other key argument was that Sturla had become temporarily insane at the time that she killed Stiles. According to her attorney, A.S. Trude, Sturla's paroxysmal insanity was a direct result of dysmenorrhea, or painful menstruation. He argued that the violence Sturla endured at the hand of her lover had exacerbated her disease, which made her prone to brief losses of sanity while menstruating. Throughout the twenty-day trial, numerous character witnesses attested to both Stiles' abusive behavior and Sturla's alleged insanity. Additionally, over a dozen different physicians were called in as expert witnesses and confirmed for the court that the abuse Sturla endured was the fundamental factor in a sudden onset of insanity that caused her to kill Stiles. On December 18, 1882, in a packed courtroom, Theresa Sturla received a compromised verdict of manslaughter with the punishment of one year in prison.

The trial of Theresa Sturla is captivating as a tale of true crime and Victorian-era sensationalism, but its overall historical significance is greater than the titillation it provided Chicagoans in the winter of 1882. Sturla's story also provokes a number of important historical

\footnotetext{
${ }^{3}$ Turner, Sturla-Stiles Tragedy, 49-53.
} 
questions: What is the significance of Sturla's use of the insanity defense founded on the idea of dysfunctional female biology in a capital murder case? What is the correlation between insanity induced by dysmenorrhea and potential moral vindication for the defendant? How were Victorian notions of true womanhood and virtue applied to murderesses? How did flagrant domestic abuse, the "unwritten law," and middle-class values factor in to the public perceptions of both Sturla and Stiles? What did a legal acceptance of revenge mean for fallen women, i.e. prostitutes, at the time? Were prostitutes afforded the opportunity for upward social mobility, or were they considered irredeemable once they became a despoiled maiden?

By using this case and other dysmenorrheal insanity cases as a lens, we might better understand the connections between womanhood, female sexuality, violence, and perceptions of insanity in Victorian America. In the nineteenth century, it was generally believed that insanity among women was derivative of an inherent feminine condition of emotional instability. Sturla's story reveals that it was possible for a fallen woman to slay an abusive lover and, with the help of a skilled defense attorney, manipulate common notions of woman's nature in order to garner sympathy from the male jury. Despite entering her trial as a fallen angel who had murdered a well-respected man, Theresa Sturla's singular display of agency - the killing of the libertine who seduced and abused her-directly led to the opportunity for moral and social redemption. This allowed for the defendant not only to literally get away with murder but also improve her prospect of realizing the Victorian ideal of true womanhood. Indeed the case demonstrates the relative plasticity of the ideal of true womanhood. As an immigrant and member of the lower class, Sturla's involvement with Stiles represented her aspirations of respectability. After the murder, the public conversation centered on whether Sturla could change her ways and become a respectable woman. Although there were skeptics, the jury's verdict and overall opinion 
expressed in the press indicates that Sturla's supporters, especially in Chicago, had faith that middle-class principles and Christian morality would prevail, providing an avenue for her to become a "true woman."

Prior to the beginning of the nineteenth century, the ideal woman was a model of womanhood known as the perfect wife. The perfect wife was an active participant in the family whose most important task was childbearing. At the dawn of the Victorian era, this model gave way to the perfect lady, an ideal that was most fully developed in the upper middle class. In her perfect form, "the lady combined total sexual innocence, conspicuous consumption and the worship of the family hearth."4 As Martha Vicinus noted in 1972, "economic and social circumstances made it impossible for the working-class woman to attain the ideal of the perfect lady." However, Sturla's case illustrates how a woman might approximate the nineteenth century ideal of true womanhood.

The Cult of True Womanhood was the centerpiece of nineteenth-century female identity. Although True Womanhood was the ideal, according to Barbara Welter, it was also a "fearful obligation, a solemn responsibility" that women had, to "uphold the pillars of the temple with her frail white hand." ${ }^{, 6}$ Victorian women were believed to be "inherently more religious, modest, passive, submissive and domestic than men." A woman judged herself and was judged by her husband, neighbors, and society based on her ability to uphold the four cardinal virtues of True

\footnotetext{
${ }^{4}$ Martha Vicinus, Suffer and Be Still: Women in the Victorian Age (Bloomington: Indiana University Press, 1972), ix.

${ }^{5}$ Vicinus, Suffer and Be Still, xii.

${ }^{6}$ Barbara Welter, "The Cult of True Womanhood: 1820-1860," American Quarterly 18, no. 2 (Summer 1966), 151-174. Welter introduced the concept of True Womanhood in 1966, which became foundational in understanding the place of women in Victorian society.

${ }^{7}$ Barbara Welter, Dimity Convictions: The American Woman in the Nineteenth Century (Athens: Ohio University Press, 1976), 4.
} 
Womanhood - piety, purity, submissiveness, and domesticity. ${ }^{8}$ She was also expected to support the men in her life by helping them to overcome any of their moral imperfections. In turn, men "subscribed to the belief in woman's moral superiority and the double standard." A virtuous girl's greatest assets were her innocent spirit and, even more importantly, her physical virginity.

As a poor immigrant who began working as a prostitute in Baltimore at the age of 15, Theresa Sturla was never part the middle class. Nevertheless, she certainly admired the ideal. When she first met Stiles he convinced her to leave her home and run away with him back to his hometown of Chicago, promising they would be wed and she would never have to disgrace herself by working in disorderly houses again. Like most girls of her time, Sturla likely felt that marrying a well-to-do man such as Stiles would be a demonstrable step up in the social hierarchy and an automatic source of happiness. However, given the fact that Stiles was well aware of Sturla's past, he almost certainly did not value her for her virtue and it is questionable that he ever truly intended to marry her. ${ }^{10}$ Sturla's biggest flaw as a woman was that she lacked purity, the absence of which was considered unnatural and unfeminine. Without it, a woman like Sturla was no woman at all, but a member of some lower order: “A 'fallen woman'...unworthy of the celestial company of her sex," as Barbara Welter put it. ${ }^{11}$ Sturla believed that becoming involved with Stiles would allow her to leave her old life behind and join respectable society. In turn, she would be socially redeemed and allowed to finally realize the aspirational ideal of true womanhood. However, Stiles' mistreatment of her throughout their relationship stopped her from breaking out of her status as a fallen woman. The model of true womanhood highlights the notion that to be guilty of the crime of impurity could bring madness or death but does not

\footnotetext{
${ }^{8}$ Welter, "The Cult of True Womanhood," 152.

${ }^{9}$ Welter, Dimity Convictions, 5; Mary Louise Roberts, “True Womanhood Revisited," Journal of Women's History 14, no. 1 (Spring 2002): 150.

${ }^{10}$ Turner, Sturla-Stiles Tragedy, 42-49.

${ }^{11}$ Welter, Dimity Convictions, 23.
} 
address how a fallen woman might restore her virtue. The Sturla trial indicates that at least one avenue to redemption began with ridding oneself of the libertine responsible for a woman's fall from grace.

According to the Victorian ideal, women who abandoned virtue had no place in middleclass society and were generally cast as sirens of vice. After 1830, however, evangelical women in American cities began forming voluntary societies that were intended to care for these lost, fallen angels. These female moral reformers cast prostitutes not as irredeemable harlots, but rather as their own fallen sisters who were themselves victims of the sexual and legal double standards pervasive in urban society. The defense of these "deviant" females was born out of hostility toward licentious men and the social order that allowed them to oppress women with impunity. Prostitutes themselves became a metaphor of the oppression of all women, selling their bodies so that they became mere objects or commodities. ${ }^{12}$

In the early days of purity campaigns that attempted to challenge the double standard, the efforts of female moral reformers were countered by male opinions of prostitution. Male reformers often claimed that men were not the problem. Rather, a prostitute's sufferings were self-inflicted and the result of voluntary vice. Inverting the arguments of female moral reformers, Reverend Ralph Wardlaw asked in his Lectures on Magdalenism: "How many of our young men, the inexperienced and the thoughtless, the light hearted and gay, are...haplessly led astray by immoral women?"13 In the defense of patriarchal values, these men argued, "Loose women infest[ed] the streets of the city," and were so unashamed that they were "beyond the possibility

\footnotetext{
${ }^{12}$ Barbara J. Berg, The Remembered Gate: Origins of American Feminism (New York: Oxford University Press, 1978), 176-197.

${ }^{13}$ Rev. Ralph Wardlaw, Lectures on Magdalenism (New York: J.S. Redfield Clinton Hall, 1843), 46.
} 
of reform." ${ }^{14}$ Yet regardless of what their male counterparts said, female moral reformers fought for the moral and social redemption of their unfortunate sisters. As Nancy Cott has argued, upward mobility was indeed possible for lower-class women. Fallen women could be seen as capable and worthy of redemption because the cultural hegemony of the upper class suggested that social constraints existed for all women, regardless of class. The possibility of reformation became a predominant theme in the public conversation around Theresa Sturla before, during, and after her trial. On the eve of the Progressive Era, Chicagoans were willing to give Sturla a chance at redemption, albeit under a watchful eye. ${ }^{15}$ However, a chance at redemption was not simply a moral issue, but was also intertwined with contemporary understandings of women's biology.

By the second half of the nineteenth century, men of science generally believed that women's nature, like men's, was rooted in their biology. Historian Cynthia Eagle Russett points out that the debate over nature versus nurture represents a historical moment "in which social and scientific developments converged to create the possibility and urgency of a science of male and female nature and of the differences between them." ${ }^{\prime 16}$ Victorian physicians and scientists drew from developments in life sciences as well as on new social sciences such as anthropology, psychology, and sociology, and the new sexual science attempted to be more precise and empirical than in the past. But the practice of medicine itself became more than a scientific discipline; it was a social institution that reinforced other social institutions that, according to

\footnotetext{
${ }^{14}$ Charles Christian, A Brief Treatise on the Police of the City of New York (New York: Southwick and Pelsue, 1812), 16.

${ }^{15}$ Berg, Remembered Gate; Nancy F. Cott, The Bonds of Womanhood: “Woman's Sphere” in New England, 1780-1835 (New Haven: Yale University Press, 1977).

${ }^{16}$ Cynthia Eagle Russett, Sexual Science: The Victorian Construction of Womanhood (Cambridge: Harvard University Press, 1989), 2.
} 
Russett, "spoke with the imperious tone of a discipline newly claiming, and in large measure being granted, decisive authority in matters social as well as strictly scientific."17

The notion of a scientific connection between female sex organs and the well being of a woman's mind was well established by the medical community by 1882 . By this time, midwifery had declined as male physicians developed the new medical field of gynecology. It became the norm that women would address their health concerns with men, creating a community of physicians with the power to make sweeping claims about the correlation between a woman's sexuality and her mental health. Unlike their female predecessors, Victorian obstetricians did not represent women furthering the interest of women but served the interest of the male-dominated status quo. Medical texts and ideals were not developed to provide woman-centered answers to questions of meaning. Rather, in the words of historian Louise Lander, medical authorities "used the medical mystique to buttress the ability of the status quo to keep women in their place." ${ }^{\prime 18}$ More than any other hegemonic group, nineteenth century male physicians ultimately defined the place of woman in society. Medical authorities regarded man as the norm and woman as the defective "other." Woman was so defective that she required the creation of an entire medical specialty devoted to caring for her unique disorders. ${ }^{19}$

Interactions between male physicians and female patients led medical professionals in the burgeoning field of psychiatry to make assertions about the supposed control that women's reproductive organs held over their bodies, of which there was no parallel in the male. It was believed that a man's sexual impulses were subject to his will and could at various times be

\footnotetext{
${ }^{17}$ Russett, Sexual Science, 4; Louise Lander, Images of Bleeding: Menstruation as Ideology (New York: Orlando Press, 1988).

${ }^{18}$ Lander, Images of Bleeding, 4.

${ }^{19}$ Barker-Benfield, Horrors; Halttunen, Murder Most Foul; Carroll Smith-Rosenberg, "Puberty to Menopause: The Cycle of Femininity in Nineteenth-Century America" in Disorderly Conduct: Visions of Gender in Victorian America (New York: Alfred A. Knopf, 1985), 182-196; Lander, Images of Bleeding, 7.
} 
indulged or repressed. By contrast, women's sexual organs were hidden within her body, "subject not to her will but to a biological clock of which women were only dimly aware and which they were clearly unable to control," according to Carroll Smith-Rosenberg. ${ }^{20}$ Medical specialists declared that the female reproductive system was the fundamental determinant of woman's nature, thereby asserting their own dominance over their female patients. According to Dr. John Wiltbank in 1854, "Women's reproductive organs are preeminent." It was "as if the Almighty, in creating the female sex, had taken the uterus and built up a woman around it." Not only woman's biology, but her "intellectual and moral perceptivity and forces... are feminine as her organs are. ${ }^{21}$ Physicians in a range of disciplines offered scientific explanations for the fundamental differences between men and women in order to justify the obverse social roles that deemed women unfit for public life. While popular theories about puberty and menstruation naturally conceded the existence of sexuality and expressive emotion as normal aspects of development, they also served as a warning to women that they must regulate their emotions and confine themselves to the home, otherwise, as Smith-Rosenberg writes, "disease, insanity, and even death would surely follow. ${ }^{, 22}$ The Victorian medical establishment frequently stressed that deviance and derangement was likely to follow the loss of virtue, illustrating the assumption that a woman's intellect was dictated by her uterus, not her brain. ${ }^{23}$

As historian Karen Halttunen asserts, nineteenth century medicine not only sexualized women's nature, it transformed normal biological function into a pathological condition that demanded routine medical intervention. Woman's reproductive process had such a "controlling influence" on her that it extended to her mental state. Hysteria, a "morbid state" in the male, was

\footnotetext{
${ }^{20}$ Smith-Rosenberg, "Puberty to Menopause," 183.

${ }^{21}$ As quoted in Smith-Rosenberg, "Puberty to Menopause," 184.

${ }^{22}$ Smith-Rosenberg, "Puberty to Menopause," 188.

${ }^{23}$ Welter, Dimity Convictions, 21-41; Halttunen, Murder Most Foul, 172-207.
} 
considered "the natural state" in the female. Pregnancy, childbirth, lactation, and menstruation were conditions that predisposed all women to the dangerous state of "temporary insanity" in which they were more prone than men to act abnormally. In these cases, "strange thoughts, extraordinary feelings, unseasonable appetites, criminal impulses, may haunt a mind at other times innocent and pure." 24

Doctors such as Augustus Kinsley Gardner, who jointly specialized in obstetrics and insanity, argued for the intrinsic connections between female sexuality and insanity, making womanhood itself a form of deviance. One explanation for the takeover of female sexuality lies in the fact that male practitioners believed that women were simply too dangerous to be left in the incompetent hands of their own sex. At the same time, however, male physicians often expressed a pronounced repugnance against their own work. This phenomenon was the result of a complex of male attitudes toward female sexuality that mingled fear with hatred and disgust, shaped by the belief that masculine identity was dictated by rigorous self-control. The ideals that constituted middle-class manhood created "autophobic" male sexuality, "such that erotic arousal was chronically attended by dread and was experienced as disgust and guilt when it was felt to stray beyond the boundaries of self-control," according to T. Walter Herbert. ${ }^{25}$ In turn, men projected that dread and disgust onto women, the source of their sexual arousal. Implicit in the ideal of female passionlessness was an underlying fear that at any moment a woman would undermine male self-command by succumbing to sexual appetite. According to Halttunen, "men

\footnotetext{
${ }^{24}$ Halttunen, Murder Most Foul, 188-189; Smith-Rosenberg, "The Hysterical Woman: Sex Roles and Role Conflict in Nineteenth-Century America," in Disorderly Conduct, 197.

${ }^{25}$ T. Walter Herbert, Dearest Beloved: The Hawthornes and the Making of the Middle-Class Family, (Berkeley: University of California Press, 1993), 143.
} 
insisted on women's innate purity in an effort to overcome their dread of female sexual pollution. ${ }^{26}$ Those feelings of dread largely emanated from the very existence of menstruation.

During her trial, Sturla's menstruation became a central issue and major subject of debate between the prosecution and defense. However, the defense of insanity induced by dysmenorrhea was not simply a medical matter, as it was believed at the time that biology equated to destiny. Victorian physicians often linked promiscuity and social class, characterizing lower-class women as overtly sexual beings who did not feel the necessity of self-control. Additionally, it was commonly believed that menstruating women were prone to temporary insanity and fits of aggression or violence. Women under excessive menstrual influence, English physician Edward Tilt wrote, "should be incarcerated for the length of their menstruating years" for their own good and that of society. ${ }^{27}$ For these reasons, Feminist scholar Louise Lander contends that the function of menstruation itself should be looked at as more than a biological phenomenon, but rather a "cultural event intimately bound up with larger questions of the place of women in society. ${ }^{28}$ During Sturla's trial, her attorney linked his client's class, sexuality, and criminality, together shifting her menstruation from the realm of biology to that of culture. ${ }^{29}$

For both women and physicians of the Victorian era, menstruation was surrounded by ambivalence. Historically speaking, menstruation was marked as a period of danger and shame that came to exist as a punishment for Eve's transgressions. By the nineteenth century, many women viewed their own menstrual blood as peculiarly contaminated and menstruation itself as a mark of their inferiority to men. Perpetuating these notions, physicians argued that women

\footnotetext{
${ }^{26}$ Halttunen, Murder Most Foul, 189-191; Barker-Benfield, Horrors of the Half-Known Life.

${ }^{27}$ Edward Tilt, The Change of Life in Health and Disease, $4^{\text {th }}$ ed. (New York: Bermingham \& Co., 1882), 13.

${ }^{28}$ Louise Lander, Images of Bleeding: Menstruation as Ideology (New York: Orlando Press, 1988), 2.

${ }^{29}$ Smith-Rosenberg, "Puberty to Menopause," 182-196; Smith-Rosenberg, "The Hysterical Woman," 197-216.
} 
were weak, diseased, and dependent due to their menstruation. Physicians also conflated menstruation and sexuality, seeing menstruation as either a monthly peak of women's sexual desire or as a biological method of helping women to control their sexual impulses. Writing in 1844, British surgeon and physician George Rowe suggested, "Might not this monthly discharge be ordained for the purpose of controlling woman's violent sexual passions...by unloading the uterine vessels...so as to prevent the promiscuous intercourse which would prove destructive to the purest interests in civil life..." ${ }^{30}$ Victorian medical doctrine declared menstrual pain and cramps to be psychosomatic, and this social ideology of women's inferiority bred insecurities and, in Lander's words, gave “medical ideology enormous power over [women's] sense of self and their sense of reality." Menstruation represented freedom from otherwise being kept busy by the burdens of pregnancy and nursing, thus posing a potential threat to the world of men. The medical community used the menstrual cycle as a vehicle for keeping women in their place, especially when they acted in a way that threatened the existing social order. ${ }^{31}$

Another vehicle for keeping women in their place was domestic abuse, which has been an epidemic for most of American history. In the colonial period, American law did little to protect battered wives, and in the few cases in which a man was prosecuted and convicted, they usually only had to pay a small fine or simply vow to reform. Public opinion in the nineteenth century condemned the act of corporal punishment against women under the belief that their inherent gentleness and docility should exonerate them from such violence. However, this sentiment did not necessarily translate to the protection of wives against their abusive husbands, which received little public attention for most of the century. This phenomenon can be partially

\footnotetext{
${ }^{30}$ George Robert Rowe, On Some of the Most Important Disorders of Women (London: John Churchill, 1844), 27-28; Smith-Rosenberg, "Puberty to Menopause," 182-196.

${ }^{31}$ Lander, Images of Bleeding, 3-10.
} 
attributed to the fact that Anglo-American customs, laws, and religion have historically promoted a wife's subordination to her husband. ${ }^{32}$

Feminists and reformers of the antebellum era, who spoke out against the canon of domesticity that they argued oppressed women, ironically used the idealized views of family and marriage to argue for the improvement wives' status and treatment within the home. The canon of domesticity was fundamentally constrictive, however, and essentially forced women to model their behavior after an extremely narrow view of femininity in order to gain any public sympathy or legal help. In Sturla's case, then, it was absolutely critical that the murderess be established as a woman who fit the mold of proper femininity and domesticity. And the only reason she was in her position as a fallen woman was because of the man who forced her to stay there.

One of the areas of the historiography that the Sturla trial most illuminates is that of late nineteenth century crime and criminology, a subject on which there has been surprisingly little written. The most in-depth study of Victorian America's captivation with violent crime and Gothic horror is Karen Halttunen's 1998 monograph, Murder Most Foul. Halttunen’s seminal work illustrates that a fascination with murder and the killer him- or herself is a product of postcolonial American Gothic culture. Acts of murder throughout the first half of the nineteenth century "pose[d] troubling questions about the moral nature of humankind. Murder thus demands that a community come to terms with the crime - confront what has happened and endeavor to explain it, in an effort to restore order to the world." In literate societies, written narratives of murder attempted to make sense of meaningless violent incidents. ${ }^{33}$

\footnotetext{
${ }^{32}$ Myra C. Glenn, "Wife-Beating: The Darker Side of Victorian Domesticity," Canadian Review of American Studies 15, no. 1 (Spring 1984), 17-33; David Peterson, "Wife Beating: An American Tradition, The Journal of Disciplinary History 23, no. 1 (Summer 1992), 97-118.

${ }^{33}$ Halttunen, Murder Most Foul, 1-2.
} 
According to Halttunen, the Victorian construction of the murderer as a madman or woman "was the purest cultural expression of the murderer as Gothic monster." These killers were considered deformed in mind, morality, and physiology. They committed the most violent and pointless murders with the least remorse or regret, violating the enlightened understanding of human nature, in which reason and logic prevailed. Thus, the development of the insanity defense signified an effort to scientifically formalize what was incomprehensible to the liberal imagination; “"insanity' was proffered as the catch-all explanation for the homicide that was motiveless, shockingly unanticipated, heinous." The madman "was the extreme expression of the criminal alien. ${ }^{34}$

Sturla's case, however, shows that the opposite could also be true. Although she had committed a shocking and violent murder, the crime was not necessarily considered incomprehensible given Stiles' mistreatment of his paramour. In addition to the claim of selfdefense, Sturla's alleged insanity was used by the defense not to prescribe meaning to the crime itself, but to frame the defendant as the victim of innate Italian "passions" and her own diseased womanhood, ultimately establishing her as a figure of sympathy in a male-dominated courtroom.

Halttunen's study is also useful as an overview of what nineteenth century alienists believed were the root causes of insanity and homicidal mania. In some cases childhood disease or heredity was cited as a cause, while other doctors invoked phrenology as a scientific method for reading the signs of disease in the defendant's physical appearance. It is worth noting that of the many cases of homicidal insanity addressed by Halttunen, only one of those defendants was a woman: Margaret Howard, who murdered her husband's lover in Cincinnati in 1849. While the particulars of the crime differ, Howard's treatment in court foreshadowed that of Theresa Sturla. Like Sturla, Howard's physiological femaleness was recognized as the primary source of

\footnotetext{
${ }^{34}$ Halttunen, Murder Most Foul, 138-9.
} 
insanity. As Howard's own attorney claimed during her trial, "women are subject to state of constitution intimately connected with excitement of mind, rendering them at times peculiarly subject to perversion of intellect, but most commonly irritable temper." ${ }^{\text {35 }}$

Halttunen's study of criminal insanity in nineteenth century America is certainly expansive, but it is by no means exhaustive. In some ways, her overview of Victorian criminal insanity cases provokes more questions than it does provide answers. It is apparent that nineteenth century alienists had a great many theories about what could cause insanity or homicidal mania, but such cases varied so greatly in their particulars that only individual case studies truly help us understand what they mean in an historical context. One of the only comprehensive case studies of a criminal insanity case is Charles E. Rosenberg's The Trial of the Assassin Guiteau (1968), which details the story of President Garfield's killer. Rosenberg offers a close analysis of the trial and the circumstances that led up to it, and examines the ways in which politics, morality, law, medicine and psychiatry converged in the early 1880 s. While there are some key differences between the Guiteau and Sturla cases, Rosenberg's work is valuable as a model for this study for a number of reasons. The two cases are similar in that the biographies of Guiteau and Sturla functioned as mirrors of American social values. In both cases, the actual facts of the defendant's lives were overshadowed by the need of others to use them as a warning and educational tool. ${ }^{36}$ The cases are also comparable in the fact that they both dealt with the concept of "moral insanity," which itself was a point of contention among both physicians and legal professionals. British physician and ethnologist James Cowles Prichard first defined moral insanity in 1835 as "madness consisting in a morbid perversion of the natural feelings, affections, inclinations,

\footnotetext{
${ }^{35}$ Haltunen, Murder Most Foul, 220-1; Trial of Mrs. Margaret Howard (Cincinnati: E.E. Barclay, 1849), 46.

${ }^{36}$ Charles E. Rosenberg, The Trial of the Assassin Guiteau: Psychiatry and Law in the Gilded Age (Chicago: University of Chicago Press, 1968), x.
} 
temper, habits, moral dispositions, and natural impulses, without any remarkable disorder or defect of the interest or knowing and reasoning faculties, and particularly without any insane illusion or hallucinations. ${ }^{, 37}$ One important difference between these cases is the fact that, as Rosenberg points out, it is "unquestionable" that Guiteau legitimately suffered from mental illness. Rosenberg does not attempt to diagnose the assassin, but notes that twentieth century clinicians who have studied the case tend to agree in their evaluation that he exhibited characteristics of paranoid schizophrenia. This assessment is key, as it highlights the fact that Sturla did not exhibit clear signs of mental illness. It is apparent to the twenty-first century observer, however, that she did suffer extensive trauma at the hands of her abuser, signs of which were brushed off both in the press and by doctors in the courtroom as obvious indicators of her insanity.

While historians have paid attention to Victorian constructions of womanhood and medical norms as they pertain to women for many years, only fairly recently have there been studies focused on women defendants in capital murder cases. Like Sturla, virtually all these cases defined the defendant's reproductive system as an inextricable link to their misbehavior. Many nineteenth century lawyers constructed narratives that played into preconceptions about the defendant and victim. A. Cherree Carlson's The Crimes of Womanhood examines the narratives constructed during the trials of seven women in this time period, including some wellknown cases such as Madame Restelle, Lizzie Borden, and Mary Todd Lincoln. In the nineteenth century, the law was white, male, and middle class. Although this fact changed slowly after the Civil War, women of all classes were regularly excluded from the legal arena. As Carlson points

\footnotetext{
${ }^{37}$ James Cowles Prichard, A Treatise on Insanity and Other Disorders Affecting the Mind (London, 1835), 16. Many of Prichard's contemporaries in the medical field took issue with this term, largely due to the fact that he claimed patients could be "morally" insane without exhibiting any clear signs of insanity. This debate will be further discussed in the second chapter of this paper.
} 
out, "the possession of a female body dispossessed one of the right to participate in the crafting of laws controlling that body," and any privilege or preference "came as a gift from men, in the form they decided upon." 38

In the late 1980s-early 1990s, historian Robert Ireland wrote several pioneering articles about the "unwritten law" as it applied to women in the nineteenth century. Under the auspices of the unwritten law, juries generally dismissed cases in which an outraged male could justifiably kill the libertine or seducer of a woman in his life, be it a wife, sister, or daughter. Women, however, were often not afforded the same opportunity for justice. Ireland's 1992 article, "Frenzied and Fallen Females," published in the Journal of Women's History, highlights women defendants and examined the relationships between sexual dishonor and violence, femininity and insanity, and rage and law. ${ }^{39}$ In a study of cases in 1843-96, Ireland has found the invention of an unwritten law that frequently excused killers who avenged sexual dishonor. According to Ireland, men had a duty to protect women from "slimy, snake-like libertines" and to punish "Eve-like women who too readily embraced those libertines." ${ }^{40}$ Male murderers were often portrayed as protectors of women's virtue. Woman defendants, on the other hand, were generally represented as biologically weak, suffering from hysteria that rendered them legally insane and thus innocent of criminal liability. Conversely, prosecutors characterized these women as inherently licentious and responsible for the evils of society. These competing characterizations were precisely what occurred during Sturla's trial. ${ }^{41}$ Most defendants— both men and womenin unwritten law cases pleaded insanity, but the conceptual foundation for this defense was

\footnotetext{
${ }^{38}$ A. Cherree Carlson, The Crimes of Womanhood: Defining Femininity in a Court of Law (Urbana: University of Illinois Press, 2009), 4.

${ }^{39}$ Robert M. Ireland, "Frenzied and Fallen Females: Women and Sexual Dishonor in the NineteenthCentury United States," Journal of Women's History 3, no. 3 (Winter 1992).

${ }^{40}$ Irelend, "Frenzied and Fallen Females," 99.

${ }^{41}$ Irelend, "Frenzied and Fallen Females," 99.
} 
bound strictly by social constructs of sexuality. Men would claim that their insanity resulted from a temporary rage over manly dishonor, while female insanity was derivative of an inherent condition of emotional instability emanating from their reproductive system. ${ }^{42}$

What is lacking in the existing literature is a synthesis of the historical elements of nineteenth century womanly ideals, women's health, and femininity as they played out in a court of law. In the proper light, the trial of Theresa Sturla represents the fusion of these components. By the latter part of the nineteenth century, as Sturla's case demonstrates, a fallen woman could realistically use the unwritten law to her advantage, opening an avenue toward moral and social redemption. Her trial deserves a feminist treatment that serves to emphasize the male-dominated court's seizure of Sturla's sense of self and of her own reality by portraying her as a victim at the mercy of her own menstruation. At the same time, Sturla's murder of her abusive seducer garnered the sympathy of women from both the underclass and respectable society, revealing a cross-class sisterhood that existed in Chicago near the turn of the century.

The murder occurred at a significant moment in Chicago's history. In the late nineteenth and early twentieth century, the city was internationally renowned for its abundance of vice and violence. Chicagoans struggled with the pervasiveness of vice, especially prostitution, in their city. Vice was relatively contained in the red-light districts on the south side of the city, but the municipal government made little minimal efforts to expunge prostitution. This, combined with the massive numbers of young, single men arriving in the city at the time allowed the sex trade to thrive well into the twentieth century. In his extensive study of homicide in Chicago, Jeffrey Adler found that at the turn of the twentieth century, the city experienced more homicides than any other urban center in the United States. Chicago murderers, Theresa Sturla included,

\footnotetext{
${ }^{42}$ Irelend, "Frenzied and Fallen Females," 99-100.
} 
"insisted that violence was a logical response to the pressures and tensions they encountered." ${ }^{, 4}$ In the midst of all this violence, many Chicagoans and visitors to the city expressed the necessity for dramatic social change. In the summer of 1876, evangelist Dwight L. Moody selected Chicago as the fourth of five major cities from which to launch a massive and ambitious program to revive and evangelize America. The three-month revival campaign was considered a spectacular success among many contemporary observers. This included one of the Chicago's most elite citizens, Marshall Field, who arranged a special service for his employees presided over by Moody and his associate, Ira D. Sankey. ${ }^{44}$

The 1870s and 1880s saw a remarkable wave of local women-led reform efforts to improve Chicago society. In 1874 Frances Willard, former Dean of the Woman's College at Northwestern University, took over the leadership of the local Women's Christian Temperance Union, directly leading to the formation of abstention societies such as the Temperance Reform Club and the establishment of the Woman's Temperance Publishing Association in 1880. Paralleling the efforts of the temperance movement, groups such as the House of the Good Shepherd and the Chicago Erring Woman's Refuge for Reform were formed to focus on the problems of vice, prostitution, and the reformation of fallen women. The Moral Educational Society, formed in 1882 , attempted to disseminate information on marriage and parenthood, the abolition of vice, and the moral training of youth. In 1886, the Florence Crittenton Anchorage of the W.C.T.U. was founded "to care for unfortunate girls who have been led astray and to protect the innocent and friendless from being led into the haunts of sin of a great city." ${ }^{45}$ The same year saw the organization of the Protective Agency for Women and Children, which, according to

\footnotetext{
${ }^{43}$ Jeffrey S. Adler, First in Violence, Deepest in Dirt: Homicide in Chicago 1875-1920 (Cambridge: Harvard University Press, 2006), 1-5.

${ }^{44}$ Darrel M. Robertson, The Chicago Revival, 1876 (Metuchen: The Scarecrow Press, Inc., 1989), 1-19.

${ }^{45}$ Citizen's League of Chicago, Eleventh Annual Report, quoted in Bessie Louise Pierce, A History of Chicago Volume III: The Rise of a Modern City 1871-1893 (New York: Alfred A Knopf, 1957), 458.
} 
reform publication The Christian Union, endeavored to afford "protection from all offences and crimes against the purity and virtue of women and children." ${ }^{, 46}$

The Sturla trial occurred just as these groups and others were initially organizing and provided early Progressive Era reformers a heartbreaking model of exactly what could go wrong if men and women did not refrain from vice and licentiousness. Within the Chicago reform movement, the direct result of Sturla's trial was the work of O.E. Turner. Using trial transcripts, newspaper reports, and his own recollections of the trial, Turner wrote and published the SturlaStiles Tragedy in 1883, less than a year after the end of the trial while Sturla was still in prison. Unfortunately, the official trial transcripts have been lost to history, making Turner's words our only direct access to the Sturla trial. However, Turner does provide lengthy verbatim accounts of what was occurred in court, verifiable by newspaper reports that printed the transcripts following each day of the trial. I have used Turner's book extensively for this study, and have made note of instances in which I quote the author's words directly versus his use of contemporary printed materials.

In addition to providing a detailed account of the trial itself, Turner framed the lives and relationship of Theresa Sturla and Charles Stiles as a morality tale that might educate the citizens of Chicago. Through the first half of the nineteenth century, murder narratives shifted from the didactic execution sermons that had the role of addressing transcendent matters of salvation to the "worldly particulars" of the criminal, i.e., biographical background, social context of the crime, the sequence of events culminating in murder, and specific details of time and place. ${ }^{47}$ Around the middle of the century, popular literature began to reconstruct the murderer from common sinner to "moral alien," a response to new understandings of human nature prompted by

\footnotetext{
${ }^{46}$ The Christian Union, Feb. 6, 1892, 270; Pierce, A History of Chicago Volume III, 458-487.

${ }^{47}$ Halttunen, Murder Most Foul, 34.
} 
the Enlightenment. ${ }^{48}$ Karen Halttunen has examined a historiographical debate regarding the use of sensationalism in the nineteenth century. While some previous scholars have regarded criminal narratives as sensationalism "for its own sake," she argues instead that it was a didactic tool. ${ }^{49}$ Turner's book exemplifies this shift, not acting as a sensationalistic attempt to capitalize on popular interest in the crime, but serving the cultural purpose of assigning meaning to the violent event. Sturla-Stiles Tragedy is the main primary source document used for this study, but I have also drawn from a great number of local and national newspaper reports, medical documents, and periodicals published by those active in the reform movement.

This thesis is divided into three chapters. Chapter one covers the four months between Sturla's arrest just after the murder and the beginning of the trial, explaining the fact that the press illustrated ambivalence among Chicagoans who sympathized with a fallen woman after the death of a prominent and well-known member of society. I argue here that Sturla's case shows the relative plasticity of Victorian views of social class, which were based on gendered notions of morality. Chicagoans learned early on that Stiles had betrayed the ideals of middle-class masculine respectability, allowing for the prostitute who killed him to become an object of sympathy in the eyes of the public.

Chapter two covers the trial itself, providing an analysis of the witnesses, testimonies, and evidence. The main argument of this chapter centers on the idea that notions about criminality and insanity were culturally defined. As they appeared as expert witnesses, medical professionals established a biological understanding of insanity, which was then mirrored by lay witness testimonies. These medical concepts clashed with nineteenth century legal understandings of moral culpability, which were based in Enlightenment notions of free will.

\footnotetext{
${ }^{48}$ Halttunen, Murder Most Foul, 35.

${ }^{49}$ Halttunen, Murder Most Foul, 2-3.
} 
This conflict became even more pronounced in cases such as Sturla's, in which murderesses claimed self-defense and insanity. Sturla became a sympathetic figure in court as she stood at the intersection of competing discourses about crime and insanity.

The third and final chapter explains that self-defense and insanity became secondary issues behind Victorian ideals of morality, and I argue that the trial came to represent a crisis of class and morals that was brewing at the dawn of the Progressive Era in Chicago. Throughout the trial, Sturla received public support from two well-known women in the community: Madame Carrie Watson, who represented vice; and Mrs. Hortensia Black, an important member of evangelical reform movements in the city. These two women came to embody the public debate over whether or not Sturla was capable of redemption.

In terms of the law and the nature of society at the time, it is somewhat surprising that an incontrovertibly fallen woman was able to avoid capital punishment after murdering a man of a higher class than her own. This paper will show that Sturla was shaped into a sympathetic figure by the press and by her attorney, leading to her exoneration and an opportunity to enter respectable society after her prison sentence. Sturla's trial illustrates the connections between female sexuality, crime, violence, and perceptions of insanity in the nineteenth century, providing unique insight into unanticipated compassion from Chicago society. This case is also historically important as a mirror of American social values, reflecting the fluidity of class mobility for fallen women. There has been very little written on nineteenth century women defendants, but scholarship would benefit from giving these women the attention they deserve. Dysmenorrhea-induced insanity cases like Sturla's indicate that a "fallen angel" might well rise again and become a true woman with a single pull of the trigger. 


\section{CHAPTER I: “A WANTON'S REVENGE”}

The road to Theresa Sturla's moral vindication ended with the jury's verdict on the twentieth day of her trial, but it began well before the proceedings - in the days immediately following her arrest. Stiles' death and the subsequent trial were highly sensationalized by local and national newspapers. In the earliest reports of the murder, the media painted Stiles as a bright, generous, well educated, and naturally talented "man of the world." Despite the fact that his intimates recognized him as "morally shaky," Stiles remained a respected man in the world of Chicago commerce who moved through society "by virtue of his birth, natural ability, which gave him position, and of his peculiar social qualities." Sturla, on the other hand, was portrayed as a "vindictive and continually threatening" young woman of "doubtful repute." 50 The murderess initially billed as "the green-eyed monster" and portrayed as a typical "ruined" woman whose propensity for crime was predictable, however, quickly became the protagonist of the story when the media began sharing the details of the couple's relationship. News reports revealed that Stiles had lured his paramour to Chicago under the promise of marriage, but had never followed through in the five years since. He also forced her to continue working as a prostitute in order to fund his gambling habit after having promised in vain to help her become a respectable woman. ${ }^{51}$ It was true that Sturla had led a life of vice since she was a teenager, but to a readership interpreting these events through Victorian understandings of gender, sex, and violence, Stiles' behavior and mistreatment of Sturla outweighed his superior social status. Stiles' betrayal of Victorian ideals for a man ultimately led to the media largely depicting him not as an unfortunate man slain by his lover, but a sly libertine who likely deserved what he got.

\footnotetext{
50 “The Wages of Sin," The Daily Inter Ocean, July 11, 1882, 1; "Palmer House Tragedy”, Chicago Daily Tribune, July 16, 1882, 8; "She Killed Her Man," Daily Arkansas Gazette, July 11, 1882, 4.

51 “A Wanton's Revenge," Chicago Daily Tribune, July 11, 1882, 3.
} 
Typically, in sensationalized cases of violent crime involving a prostitute, the woman was the victim and the man who had committed the act was often not held legally responsible. Exemplifying this was one of the most infamous cases of the century: the 1836 murder of a young prostitute named Helen Jewett. Following the discovery of Jewett's burned and mutilated corpse, a nineteen-year-old clerk named Richard Robinson was tried for the murder. When Jewett's madam and other prostitutes testified against Robinson, the trial shifted focus from the defendant to a judgment of the witnesses' integrity and moral character. Robinson was ultimately acquitted despite a public belief that the weight of evidence was against him. The Jewett murder illustrates that the life of a prostitute was valueless, yet that of a man who engaged in activities of equal licentiousness would be preserved, even at the expense of justice. ${ }^{52}$

Through the Sturla case, Chicagoans clarified a social order in which class and gender were intricately entwined with moral expectations, applying gendered notions of morality to both parties. The public expressed great contempt for Stiles' behavior, allowing Sturla to become a figure of sympathy. One aspect of the case that makes it particularly significant is that it represents a moment in which the public held a prostitute—and a murderer, no less—in higher regard than the man whose blood she spilled. Public opinion was likely dictated by two things. The first was the many first-hand accounts of Stiles' aggressive behavior, confirmed by Stiles himself in the form of letters addressed to Sturla, which were printed in the press within weeks of the murder. Second, Sturla granted nearly endless interviews to reporters between July and November while she awaited her trial, giving her the opportunity to address a city full of curious spectators and justify her actions before the trial began. Thanks to the attention from the press, the public learned early on that Stiles had betrayed the ideals of middle-class masculine

\footnotetext{
52 Patricia Cline Cohen, The Murder of Helen Jewett: the Life and Death of a Prostitute in NineteenthCentury New York (New York: Alfred A. Knopf, 1998); Barbara J. Berg, The Remembered Gate: Origins of American Feminism (New York: Oxford University Press, 1978).
} 
respectability by constantly gambling away all of his money, abusing his lover, and forcing her to work in a brothel to fund his habit.

From the very first reports of Stiles' murder, the press illustrated Chicago's fascination with such a sensational crime and its simultaneous ambivalence surrounding the circumstances of the case. The treatment of the couple in the media is reflected in O.E. Turner's Sturla-Stiles Tragedy. Aside from acting as a chronicler of the trial in question, Turner wrote the Sturla-Stiles Tragedy as a cautionary tale. His intention with the book was not to appeal "to the grosser instincts of an idle and perverted curiosity which fattens upon sensational tales of tragedy and over-drawn fiction." Instead, he aimed to "probe to the bottom of the mass of corruption which like a festering sore is eating to the very hearts-core of society." According to Turner, the lives of both Sturla and Stiles "were under a perpetual contamination of body and mind," embodying the corrupt and perverted social relations that were the root cause of the evil in Chicago and American society at large. ${ }^{53}$ There are no records that clearly indicate exactly who O.E. Turner was, but the final chapter of Sturla-Stiles Tragedy indicates that he was a moral reformer who regarded the entire saga as a morality tale from which Chicagoans must learn the repercussions of living lives of vice and corruption. ${ }^{54}$

Turner gives biographical accounts of Theresa Sturla and Charles Stiles, the facts of which he hopes "may incite thought and subserve a moral purpose," beginning with establishing Theresa as a victim of circumstance. ${ }^{55}$ Reflecting common nineteenth century essentialist ideas about race, Turner remarks that in Italy, the social standard is such that women are the inferior and slave of man. For Italian women, "virtue and purity [have] no foundation in principle, being

\footnotetext{
${ }^{53}$ Turner, Sturla-Stiles Tragedy, 10-11.

${ }^{54}$ Chapter Three will further analyze Turner's treatment of the crime as a morality tale and the SturlaStiles Tragedy as an early Progressive Era document.

${ }^{55}$ Turner, Sturla-Stiles Tragedy, 10-11. In order to construct these biographies of the couple, Turner pieced together multiple newspaper accounts printed shortly after the murder.
} 
only a condition which the superior power of man enforces upon woman that he may better gratify his own selfish and lustful passions. ${ }^{, 56}$ Having hailed from the country that gave birth to some of the greatest philosophers, the greatest libertines, and the greatest tyrants the world has ever known, Italian "religious and social ideas and customs were interwoven with the entire fabric" of Theresa's life. ${ }^{57}$ The impressionable young Italian began down her wayward path when she became romantically involved with another Italian immigrant named Gregaio Galvenio. $^{58}$

Sturla and Galvenio had known each other since they were small children and as they got older their attachment developed into what Turner called a "fervent passion." Galvenio had led Theresa's parents to believe that he would marry their daughter. Theresa, however, was oblivious to the "knowledge of her own nature and the insidious leadings of passion," and was subjected to Galvenio’s “will and caprices.” When Theresa was fourteen years old, Galvenio "accomplished her ruin" following a night of "Bacchanalian revelries." "59 Galvenio persuaded Sturla to take apartments at the bagnio of Madame Fay, ostensibly for the purpose of having instructions in music. Sturla's parents eventually learned of their daughter's relations with Galvenio and disowned her, leaving her to fend for herself at the age of fifteen. Turner concludes Sturla's biography with a show of pity:

Let her sin be what it would, in consideration of the tenderness and inexperience of her years, the indiscretion and final cruelty of her parents, can there be a

\footnotetext{
${ }^{56}$ Turner, Sturla-Stiles Tragedy, 14.

${ }^{57}$ Turner, Sturla-Stiles Tragedy, 13-14.

${ }^{58}$ In the late nineteenth and early twentieth centuries, Italian immigrants had an "inbetween" racial status in America. They did not experience racialization in the same way as blacks, but they were also often categorized as nonwhite. For more on categories and ideas about race and ethnicity in this period, see David R. Roediger, Working Toward Whiteness: How America's Immigrants Became White, (New York: Basic Books, 2005) and Matthew Frye Jacobson, Whiteness of a Different Color: European Immigrants and the Alchemy of Race, (Cambridge: Harvard University Press, 1998).

${ }^{59}$ Turner, Sturla-Stiles Tragedy, 16.
} 
mother in all the land whose heart would not reach out toward her in commiseration and a desire to rescue rather than condemn her? ${ }^{60}$

Turner's reflections on the life of Theresa Sturla mirror much of the rhetoric found in newspaper reports and the trial itself. The young Italian had lacked the virtue and purity expected of women by American society and was inherently influenced by impulsivity and passion. She had indeed led a life of sin, but she was ultimately a victim of her own cultural background, the evils of her urban environment, and most importantly, the libertine that had seduced her. ${ }^{61}$ This version of the murderess would have been familiar to a literate, late-nineteenth century audience. Imagery of the fallen woman as a guiltless victim preyed upon by evil forces had been a fixture of popular literature for fifty years by the time of the trial. Since the introduction of the penny press in the 1830 s and 1840 s, American readers were inundated with varying tales of betrayed virtue that portrayed women as innocent lambs being devoured by sly wolves. The outcast woman portrayed in literature allowed for titillation of Victorian audiences by providing a look inside the repressed secret lives of men and women. In order to generate sympathy for a character, authors writing about the life of a fallen woman had to depict her as an exploited victim. The implication of this fictional formula enforced expectations about women's sexual passivity and submission to male authority. Because she had neither chosen her fate nor expressed any sexual motivation for her actions, the fallen woman did not undermine woman's innate purity and passionlessness, allowing for sympathy from society. ${ }^{62}$ This characterization of fallen women allowed Sturla a degree of class mobility and sympathy_even as a murderess.

\footnotetext{
${ }^{60}$ Turner, Sturla-Stiles Tragedy, 17.

${ }^{61}$ For the purposes of this essay seduction refers to the Victorian definition of the word, i.e., the act of a man persuading an unmarried woman to engage in sexual intercourse.

${ }^{62}$ Barbara Meil Hobson, Uneasy Virtue: The Politics of Prostitution and the American Reform Tradition (New York: Basic Books, 1987); Smith-Rosenberg, Disorderly Conduct, 109-128.
} 
From his birth in 1850 until his death at Theresa's hand, Charles Stiles had led a privileged life. He was born in Dixon, Illinois to Sybil Catherine Stiles and General E.B. Stiles, a prominent local politician and businessman. As a young man he spent several years touring Europe and receiving education at universities in Dresden and Heidelberg, eventually gaining fluency in German, French, and Italian. When he returned to Chicago he began his professional career as a caller with the Grain, Provision, and Stock Board. According to the Chicago Daily Tribune, Stiles quickly became known as "the lightning caller" and was "without doubt one of the best callers in the United States. ${ }^{\prime 63}$ His "ready tongue" and "bright intellect" made him popular "among men of his kind, and no party was complete without him," noted another news report. ${ }^{64}$ Despite his professional and social prowess, even the earliest newspaper reports recognized that Stiles had chosen "a fast life, like hundreds of others in [the] city, living only in the present." ${ }^{\prime 65}$ Stiles' hallmark was his "perfect mania for gambling in every conceivable form." He did not distinguish a "moral difference" between betting $\$ 10,000$ on the turn of the stock market and $\$ 100$ on cards, or $\$ 1,000$ on the result of a horse race. To him, "one way of risking money was as legitimate as another."

Stiles' propensity for gambling and his association with other fast young men perfectly place him in the realm of what had become known as sporting culture, which had originated in 1830s New York City. Male sporting culture developed in nineteenth century urban environments that had drawn young men away from their families and into living and working situations that emphasized homosocial relationships. These young men, who often lived in boardinghouses and had their own money to spend, could find enjoyment in any number of the

\footnotetext{
63 “A Wanton's Revenge: Biographical” Chicago Daily Tribune, July 11, 1882, 3.

64 "He Sowed the Wind and He Reaped the Whirlwind," Louisville Courier Journal, July 13, 1882, 5.

65 “A Wanton's Revenge," Chicago Daily Tribune, July 11, 1882, 3.

66 "He Sowed the Wind and He Reaped the Whirlwind," Louisville Courier Journal, July 13, 1882, 5.
} 
city's offerings of cockfighting and bare-knuckle prizefights, liquor, theatrical entertainment, and commercial sex. ${ }^{67}$ Young men migrating from rural environments were warned of the dangers that awaited them in the city and a culture that was at odds with middle-class respectability. Undoubtedly, some boys and men found these warnings appealing rather than threatening, as freedom from middle-class constraint was what they desired. ${ }^{68}$

This alternative urban world celebrated an ideal of leisure devoted to the pursuit of pleasure. Like New York City, Chicago offered opportunities for a great variety of theatrical performances, gambling, intoxicating drinks, and blood sports. The sociable world of sporting allowed for the fraternity of men of all ages and socioeconomic backgrounds to unite in the pursuit of leisure, thrills, and pleasure. One defining element of sporting culture was the dream of unrestricted male heterosexuality. Women were nothing more than instruments of male pleasure to be used and discarded with impunity. For a sporting man like Stiles, a wife equated to the limitation of a man's sexual and personal freedom, while the prostitute represented something of an abstract sexual object. ${ }^{69}$

Labeled a "confirmed gamester and as fast a man as there was in town," by the Chicago Times, Stiles had seduced Sturla. The charismatic and smooth-talking libertine met the woman who would ultimately end his life in 1877 on a trip to Baltimore when she was just sixteen years old. At that time, Sturla was working as an "inmate" at the apartments of Madame Fay under the name "Italian Effie." 70 She was well known at the brothel due to her skillful piano playing and

\footnotetext{
${ }^{67}$ Helen Lefkowitz Horowitz, Rereading Sex: Battles over Sexual Knowledge and Suppression in Nineteenth-Century America (New York: Alfed A. Knopf, 2002), 127. According to Horowitz, the term "sporting" was a perfect euphemism for elements of male urban life. Besides its obvious meaning of recreation and amusement, it also emanated from slang of an earlier era that connoted coition.

${ }^{68}$ Horowitz, Rereading Sex, 125.

${ }^{69}$ Horowitz, Rereading Sex, 127.

70 “The Girl's Career in Baltimore," Chicago Daily Tribune, July 11, 1882, 3.
} 
operatic singing voice and she gained something of a following, as many men admired her for her beauty and character. O.E. Turner gave this description of Theresa:

Her voice, whose richness and capacity was beyond that of the canary bird or nightingale; her large, dark eyes flashing beneath the dark silken lashes and heavy arching brows; her abundant waiving hair, whose gloss and beauty outrivaled that of the oft-quoted raven's wing; her lithe and graceful form, and ardent, impulsive ways were her attractions. ${ }^{71}$

Enamored with Sturla, Stiles spent nearly every day of his trip in her company. Before leaving Baltimore, Stiles gave Sturla a glowing account of his hometown of Chicago, representing himself as one of the city's most prominent men. He told her he had great influence with the dramatic press "and that he could by the wave of the hand raise her to great prominence on the stage, and as a shining star in the high circles in which he was a distinguished character." For several weeks after leaving town, he regularly wrote her letters full of fervent expressions of love that were frequently accompanied with solicitations for money to cover his debts. $\mathrm{He}$ continued to give her excited descriptions of the attractions of the city and, according to Turner, "enthused her brain with high expectations" of her potential for success as a performer. Sturla was finally convinced and travelled to Chicago to be with Stiles, only to spend the next five years enduring violent physical and emotional abuse and being forced to work at a brothel in order to bankroll her paramour's gambling habit. ${ }^{72}$

The Chicago public was introduced to the Stiles murder the day after it transpired when it was given great attention in all the city's major papers, including the Chicago Daily Tribune, the Chicago Times, and the Daily Inter Ocean. Big-city newspapers such as these were themselves a

\footnotetext{
${ }^{71}$ Turner, Sturla-Stiles Tragedy, 15.

${ }^{72}$ Turner, Sturla-Stiles Tragedy, 30-33.
} 
technological wonder, designed to entertain and attract everyone from the rich to illiterate poor. Journalists of the late nineteenth century specialized in crime stories, entertaining features, and stories of the downtrodden that served to entertain the masses and "rake the muck." ${ }^{, 73}$ Prior to the nineteenth century stories of crimes were transmitted to the public largely in the form of the execution sermon. This sacred narrative focused on the spiritual condition of the criminal rather than the bloody actions and judicial process that led to their condemnation at the scaffold. ${ }^{74} \mathrm{By}$ the time of Theresa's trial, however, the sacred narrative had been replaced by secular accounts such as criminal biographies and printed transcripts of murder trials, turning the attention of the public to the crime itself and its unfolding in real time. As Karen Halttunen has observed, many scholars explained that the genre of the criminal narrative was an expression of sensationalism for its own sake. Instead, she argues that these sensationalistic accounts represented a new and different approach to making sense of violent crime. ${ }^{75}$ In large cities like Chicago, the sensational penny press accompanied the emergence of a mass readership that sought meaning in the face of violence and looked for a new way of facing the crime of murder. ${ }^{76}$

As the crime occurred in the early hours of the morning, the Chicago papers initially picked up the story that very afternoon. The following day, on July 11, 1882, an in-depth article entitled "A Wanton's Revenge" was published in the Chicago Daily Tribune, taking up a full page of the twelve-page issue and containing all the trappings of sensational journalism that often dominated the urban press of the time. The article detailed the particulars of the murder, gave biographies of both Sturla and Stiles, and included witness accounts from other Palmer

\footnotetext{
${ }^{73}$ David B. Sachsman, After the War: The Press in a Changing America, 1865-1900 (New York: Taylor \& Francis, 2017), xiii, xxiii.

${ }^{74}$ Halttunen, Murder Most Foul, 2.

${ }^{75}$ Halttunen, Murder Most Foul, 2-3.

${ }^{76}$ Amy Gilman Srebnick, The Mysterious Death of Mary Rogers: Sex and Culture in Nineteenth-Century New York (New York: Oxford University Press, 1995), 10, 65-67.
} 
House boarders and interviews with a handful of people who could account for the dysfunction of the couple. Considering the length and detail of the article in the city's most prominent newspaper, this piece would set the tone for how the public would regard the murderess and her victim months before her trial began.

Beginning with the subheading "A Deliberate Murder," the Tribune article was initially sympathetic to Stiles, "a young man known to tens of thousands in Chicago," and painted Sturla as little more than a vengeful prostitute. As it was reported, the couple had been living together for five or six years, maintaining a relationship "not recognized by the law." Stiles had allegedly grown tired of her, which lead Sturla to establish her own bagnio "on a South Side thoroughfare, where she offered opportunities to other women to become as bad as she was." The couple repeatedly came together and parted during their years together, and Stiles made efforts to "quit himself of the complication but the woman had a great hold upon him." Sturla repeatedly told reporters that throughout their relationship she had handed Stiles a "very large percentage of the wages of her sin." It appears that at least some members press had a difficult time believing this, as one reporter proclaimed that there was "too much reason to believe...that he accepted for his own use the money which she earned" by working as a prostitute. ${ }^{77}$

The article goes on to explain that although the couple never actually married they labeled themselves man and wife, Sturla having unofficially adopted the name "Madeleine Stiles." Friends and acquaintances of Stiles were apparently aware of the way he treated his mistress, but largely dismissed his actions in favor of the great admiration they had for him and his business talents. As one of his coworkers said Stiles "was a genial, whole-souled fellow among the boys. He had two characters — like a good many other men. He had no moral principle, and treated that woman badly. There is no doubt that she had given him thousands of 77 “A Wanton's Revenge: A Deliberate Murder,” Chicago Daily Tribune, July 11, 1882. 
dollars." Another friend of Stiles discussed his opinion that "the Italian [was] a pretty good woman for one of her class," and that she had been "badly abused." Despite his esteem for Stiles, the friend admitted that he "was no good." Not long before he was killed, Stiles told this friend, “I am going to live with Madeleine again. A fellow must live with somebody. I don't want to get married, because I might get tired of a wife in a month.,"78

When Sturla's trial began in November, the defense would argue (with support from expert witnesses) that the abuse she suffered at the hand of Stiles was one of the key factors leading to her insanity. The Tribune helped to establish the extent of Stiles' abuse toward Sturla by including commentary from several people who were familiar with the couple and the way Stiles treated Sturla. One of these was William A. Pinkerton of the Pinkerton Detective Agency, who would take the witness stand during the trial several months later. Pinkerton told the Tribune that about three years prior to the murder, Stiles had called him, stating that he had "been insufferably annoyed by the woman." Stiles claimed that Sturla had been extorting large sums of money from him, and had made him a laughing stock at the Board of Trade by sending him a bouquet of "carefully selected thistles and cabbage-leaves." When Pinkerton went to Sturla's home to confront her about the claims, he was surprised to learn that it was actually Stiles who owed her large sums of money and that she simply wanted to be left alone. After hearing about details of the abuse she had suffered, Pinkerton made an official report and gave it to Stiles with the order to keep away from her, reminding him that "she was an Italian and of a revengeful nature, and would certainly protect herself in case of an emergency." A short time later, Stiles got "comfortably drunk" and broke the order he had been given by going to Theresa's apartment. Pinkerton was called yet again, chastising Stiles for breaking his promise not to return. Stiles replied that by calling the Pinkertons in the first place, he "only wanted to

78 “A Wanton's Revenge: On ‘Change,” Chicago Daily Tribune, July 11, 1882. 
make a bluff against the woman." The shrewd detective warned him that Theresa's "impetuous nature would brook no more insults, and that unless he (Stiles) conducted himself better bodily harm would certainly happen to him at her hands." 79

The most telling feature of the entire Tribune piece were the twenty-one letters published in the article. The letters were intended to "give the public a fair idea as to the exact relations between Stiles and his mistress," and give the historian the only unfiltered record of their relationship. In cases of violence between lovers, it was not unusual for letters to appear in print or as evidence during a trial. For voyeuristic Victorian audiences, these private expressions of emotion were appealing because they were examples of genuine romantic prose and because many believed in the bare truthfulness of love letters. ${ }^{80}$ Except for one short note signed "Effie," all of the printed letters were addressed to Sturla from Stiles. These give us great insight into the nature of their relationship, particularly his treatment toward her. Some of the notes mix words of affection with appeals for pity and money. Others express regret for past misconduct and request forgiveness.

Several letters in particular stand out among the rest, as they contain manipulative instructions and warnings. With these letters, the public saw the intimate record of a supposed gentleman forfeiting his social standing by betraying the ideals of Victorian manliness. By all accounts, Theresa seldom drank alcohol, but Stiles seems to have repeatedly projected his own behavior onto her by forbidding her from drinking: "Be a good girl and don't drink, whatever you do," he writes in one letter. He ends another with, "I shall continue in every one of my letters

\footnotetext{
79 “A Wanton's Revenge: Pinkerton's Aid Used as a Bluff," Chicago Daily Tribune, July 11, 1882.

${ }^{80}$ Gordon Morris Bakken, Women Who Kill Men: California Courts, Gender, and the Press, (Lincoln: University of Nebraska Press, 2009), 9-10.
} 
to warn you against drink. You know its subtle evil effects as well as any one." ${ }^{\not 1}$ Stiles attempted to mold Sturla into the proper ideal for a woman, but disregarded his own masculine responsibilities by not offering the gallant protection afforded to that role and instead threatened her with violence. The longest and most disturbing letter among those printed in the paper includes detailed instructions for Sturla to surreptitiously communicate with the secretary of the Call Board in an attempt to get Stiles his old position back. The letter ends:

If this can be arranged, you look out for a place to live at once, and if, when I get to Chicago, I hear that you have been bad or dissipated in any way, I'll pound you black and blue [Italics in the original]. Now, please, honey, be a good girl, and I will stick to you for life. My God! I never knew how much I could love you. Please return the inclosed [sic] letter to me. Don't take a drop of champagne any more than you would so much poison, and your lot shall be a happy one. ${ }^{82}$

Stiles' letters and the accompanying article accentuate the many ways in which he failed to embody Victorian ideals of manliness. Although male passions such as ambition and aggression had been given freer reign than in an earlier time, manhood was defined by one's ability to properly channel such passions, which Stiles had clearly failed to do. Additionally, many readers likely saw Stiles not only as a man unable to control his aggression, but also unable to fulfill his gendered role due to a proclivity for gambling and drink. Although gambling was abundant in urban society, it did not align with moral imperative emphasized by Victorian social standards. The gambler was a threat to these ideals because he underscored a belief that luck

\footnotetext{
81 “A Wanton's Revenge: Correspondence Between Stiles and the Woman," Chicago Daily Tribune, July $11,1882$.

82 "A Wanton's Revenge: Correspondence Between Stiles and the Woman," Chicago Daily Tribune, July 11,1882 .
} 
mattered, suggesting that net worth did not necessarily equate to moral worth. Victorians endorsed a culture of control, which promoted the self-made man — the obverse of the gambleras its hero. By contrast, the self-made man represented success through careful cultivation of Protestant virtues and a belief that material rewards align with ethical merits. In Stiles' case, monetary worth clearly did not equate to morality. Stiles' most egregious affront to Victorian ideals was quite possibly his repeated requests for money from Sturla. A Victorian man who became the financial dependent of a woman, not to mention a prostitute, was no man at all. ${ }^{83}$

Within days of the murder, Stiles' exploitation of his mistress for money came to light in the press. As a successful caller at the Board of Trade Stiles made a salary of $\$ 5,000$, and it was not unusual for him to lose upwards of $\$ 2,000$ in a horse race. Sturla maintained that over the years he had gambled away all of his money and thousands of dollars of her money as well. ${ }^{84}$ Stiles and his ilk—-sometimes referred to as "bloods"-were admonished in the papers. These were men of ample means who, according to one Chicago paper, "entice[d] into the whirl of their dissipation others who [were] not so fortunate in the possession of wealth." Specifically, they targeted "abandoned" women who would keep them in funds by "surrender[ing] principle, decency, and honesty." Of course, these abandoned women were compelled by their "weakness and misery," and they "turn[ed] to these men as objects of special regard, and wast[ed] the love that nature places in every woman's breast upon them." ${ }^{85}$ The establishment of Stiles' status as a libertine early on in the media was significant because the Chicago public would have been well

\footnotetext{
${ }^{83}$ E. Anthony Rotundo, American Manhood: Transformations in Masculinity from the Revolution to the Modern Era (New York: BasicBooks, 1990), 1-10; Elaine Frantz Parsons, Manhood Lost: Fallen Drunkards and Redeeming Women in the Nineteenth-Century United States (Baltimore: Johns Hopkins University Press, 2003), 1-17; T.J. Jackson Lears, Something For Nothing: Luck in America (New York: Viking, 2003), 1-23.

84 "The Wages of Sin," The Daily Inter Ocean, July 11, 1882, 1.

85 “A Disgraceful Revelation," The Daily Inter Ocean, July 12, 1882, 15.
} 
aware of the murder and character of the victim and defendant well before the trial even began in November.

In these ways, the society that had created the nineteenth century model of the pure, passionless woman also invented new models for men, who were advised to practice restraint and limit incidences of sexual intercourse. Victorians deemed this to be more difficult for men than women because of man's supposed deep-seated sexual appetite. However, sexually profligate males were not automatically excused for their behavior. As Robert Ireland points out, "part of the ideology of republican virtue that created the republican wife also conceived the anti-republican libertine whose seductions of once-virtuous women were described as the works of Satan." ${ }^{86}$ However, a "male folk code" arose that complicated and undermined the theoretical model of the self-controlled virtuous male who fell from grace and became a libertine. This code dismissed sexual purity as a female characteristic and encouraged men to regularly make use of their sex organs in order to prove and preserve virility. Americans in the nineteenth century placed a higher premium on sexual virtue than at any time in their history. In order to protect notions of sexual propriety, Americans occasionally adopted extreme measures. By the time of the trial in 1882, a higher "unwritten" law had been invented that excused the murder of the libertine who had threatened the accepted sexual norms. ${ }^{87}$

It was immediate public knowledge that Sturla had been a sex worker in Baltimore before she met Stiles. Despite this, Stiles' apparent libertinism largely outweighed Theresa's moral imperfections, and the Chicago press emphasized the spark of virtue that existed inside the heart of the young harlot. One reporter remarked, "Her manners and personal beauty always secured for her an eager following. Contrary to the habits of her class, however, she saved her earnings-

\footnotetext{
${ }^{86}$ Robert Ireland, "The Libertine Must Die: Sexual Dishonor and the Unwritten Law in the NineteenthCentury United States," Journal of Social History 23, no. 1 (Autumn 1989), 29.

${ }^{87}$ Ireland, "The Libertine Must Die," 29; Barker-Benfield, Horrors of the Half-Known Life.
} 
hoarded them, in fact, to the dollar, and never drank or caroused." ${ }^{88}$ O.E. Turner supposed that Sturla's station in life was simply the result of having "naturally inherited the passions and peculiarities of the Italian people. ${ }^{\prime 89}$ When Stiles picked her up at the age of sixteen, she was, Turner wrote, "an uncultured child of one of the most passionate races on the globe." ${ }^{90}$ Victorian Americans had established a culture that emphasized sexual purity and stable marriages as the essence of social order. Fitting of that culture, debauched women were considered disgraced in the eyes of Victorian society and their lives were often considered worthless.

The press and public reactions to Sturla's case indicates the extent to which Victorian notions of class were bound by expectations of moral character and respectability. It also just how fragile this connection was, and that the public would align with a fallen woman when it became apparent that her man had abandoned his masculine responsibilities for immoral and licentious behavior. If newspaper reports are indicative of public opinion, Sturla's case shows us that it was possible for a fallen woman to garner the support of community from the confines of a jail cell. By giving regular interviews and establishing Stiles' history of abuse, Chicagoans saw not a mere harlot but a woman who had been disgraced by a man that betrayed his duty as a Victorian male. Although these sentiments came far from ensuring an acquittal in court, they would certainly be influential for Sturla's establishment as a figure of sympathy as she prepared to enter court in November 1882.

\footnotetext{
${ }^{88}$ Turner, Sturla-Stiles Tragedy, 52.

${ }^{89}$ Turner, Sturla-Stiles Tragedy, 13.

${ }^{90}$ Turner, Sturla-Stiles Tragedy, 15.
} 


\section{CHAPTER II: "THE STORY OF HER SUFFERINGS"}

In the months preceding her trial, the press had painted conflicting pictures of the woman who killed Charles Stiles. The opening statements of the defense and prosecution represented these two versions in starkly contrasting ways, both sides using Sturla as a symbol of major social issues of the day. For the state, the Sturla-Stiles relationship as a whole was "a standing menace to public morals," and Sturla herself represented wanton sexuality, impiety, and the horrors associated with free love. ${ }^{91}$ For the defense and those who openly supported Sturla during the trial, she was clearly a victim of male perfidy, lust, and power. Previous dysmenorrhea-insanity cases confirmed the belief among medical professionals that a woman who suffered seduction, desertion, or disappointed affection at the hands of a man was likely to exhibit signs of insanity. Giving credence to the defense, doctors recognized as experts on insanity testified that the behavior of the defendant was proof that women's biology created inherent mental instability that could easily lead to weakened morals and violent conduct. Medical professionals in court established a biological understanding of insanity, which was mirrored by lay-witness testimonies that attested to Sturla's peculiar behavior considered to be clear indications of madness. These notions conflicted with legal understandings of moral culpability, which were grounded in Enlightenment ideas of free will and individual agency. The male jury ultimately sympathized with Sturla, who found herself at the crossroad between competing discourses about crime, insanity, and her own biology.

Moreover, Sturla's trial reveals that conceptions of insanity and criminality were defined by gendered cultural norms of the era. The Victorian ethos about gender and sexuality shaped understandings of criminal insanity among the medical community and the public in general. Earlier notions of hysteria as a characteristically female condition transformed into a

\footnotetext{
${ }^{91}$ Turner, Sturla-Stiles Tragedy, 185.
} 
pathological disorder in the form of dysmenorrheal insanity. While alienists debated amongst themselves the nuances of what constituted various forms of insanity, some defense attorneys saw the medical establishment's naturalistic, biological interpretation of criminals on trial as a way to bolster their cases and justify their clients' actions through the authority of science. However, the belief among alienists that homicidal insane persons lacked free ran counter to how American legal professionals interpreted criminality. As we shall see, this rift between the medical and legal establishments became an issue in Sturla's trial, as it led Judge Gardner to formally disassociate the insanity argument from the overall defense in the form of his instructions to the jury.

Prior to the nineteenth century, trials followed an inquisitorial form in which the judge attempted to extract the truth from the person on trial. The newly developed adversarial system of opposing council was characterized by the presentation of contrasting images of the defendant. In an attempt to make sense of competing narratives, nineteenth century lawyers often employed sentimental theatre, using dramatic flourishes that were likely to have an emotional impact on the jury. ${ }^{92}$ In the case of the Stiles murder, Theresa Sturla enthusiastically played the role expected of a Victorian murderess. Women on trial made particularly compelling "characters" for the men who were to judge them. Victorian-era murderesses were commonly depicted in multiple, conflicting ways. As Mary S. Hartman notes, "In their own time, the lady killers of the Victorian era, whether excused or vilified, were almost never presented as the women they were. They assumed multiple identities fashioned by both themselves and by others." ${ }^{.93}$ The prosecuting attorney fashioned Sturla as a woman of "appalling nature" akin to Eve, who had employed subtle cunning in her "unfaltering resolution to make [Stiles'] death

\footnotetext{
${ }_{92}$ Halttunen, Murder Most Foul, 95-97.

${ }^{93}$ Mary S. Hartman, Victorian Murderesses, (New York: Schocken, 1977), 255.
} 
certain. ${ }^{94}$ Sturla's lawyer, in turn, described a delicate young woman who had been a victim not only of her abuser, but also of a malformed society that exiled innocent female victims of debauchees and libertines, driving them to suicide or even worse - to a life of prostitution. ${ }^{95}$

In insanity cases such as Sturla's, the display of contrasting personalities of the defendant was a key factor in whether or not a jury would find him or her guilty. During trials in which the guilt of the defendant was undisputed, lawyers could not hope to create alternate suspects or prove the absolute innocence or their client, which forced the jury to rely on the depiction of character and the conduct of the defendant to reach their verdict. In the case of female defendants, however, defense attorneys often played on the all-male jury's sense of chivalry and their inclination to protect weak and fragile women. Sturla's trial also took place during a time in which law enforcement and legal professionals argued that the criminal law must protect the innocent from the violence around them. As Jeffrey Adler observed, these sentiments likely encouraged jurors to view habitually battered women as sympathetic defendants who deserved legal protection. ${ }^{96}$

Whether or not they realized it at the time, the jury in Sturla's trial had a historically unique case on their hands. Sturla's actions stood out among those of other Chicago women murderers, and her story was distinctive among the few dysmenorrheal insanity cases that had preceded it. While the particulars varied, each of the defendants in these cases had been deemed respectable and pure before becoming involved with their paramours. Their attorneys were able to convince the jury that their clients were despoiled maidens, seduced and betrayed by men who

\footnotetext{
${ }_{94}^{94}$ Turner, Sturla-Stiles Tragedy, 89.

${ }^{95}$ Carole Haber, The Trials of Laura Fair: Sex, Murder, and Insanity in the Victorian West, (Chapel Hill: University of North Carolina Press, 2013), 1-10.

${ }^{96}$ Jeffrey S. Adler, “'I loved Joe, but I had to Shoot Him': Homicide by Women in Turn-of-the Century Chicago." The Journal of Criminal Law and Criminology (1973-) 92, no. 3/4 (Spring-Summer 2002): 886.
} 
had taken advantage of their delicate sensibilities. What, then, was a jury to do with the fallen woman in front of them; a maiden who had already been spoiled by the time she met her lover at the age of sixteen?

Committing the murder in the first place made Sturla a moral alien in the eyes of the court and of society. Utilizing the insanity defense made her a mental alien on top of that. Finally, by conflating Sturla's menstruation and biology with her alleged insanity, she became a sexual alien. For nineteenth century audiences, criminal women in general displayed traits inconceivable in a true woman, making Sturla's actions and behavior culturally incomprehensible. ${ }^{97}$ In order to make sense of the murder, it was critical for the defense to convince the jury that Sturla had been the victim throughout, and even before, her relationship with Stiles and that killing him was an act of desperation and self-preservation. Although she was not fully acquitted, the jury's verdict indicates that they saw past Sturla's fallen status, instead viewing her not only as a lifelong victim of poor circumstances who deserved a chance at moral rehabilitation, but also as a sympathetic figure who could not be held responsible for her crime and deserving of legal protection at the hands of men more responsible than the debauchee that had wronged her.

Sturla's trial also took place at a unique time in the criminal history of Chicago. Jeffrey S. Adler has found that turn-of-the-twentieth century Chicago saw a significant rise in the levels of violence perpetrated by women. This is because gender roles loosened for habitually abused wives, as the violence perpetrated against them largely excused their own violent behavior as deserved retribution. ${ }^{98}$ Although Sturla and Stiles were never married, they clearly had a longterm relationship and recognized each other in public as husband and wife. Therefore, it is useful

\footnotetext{
${ }^{97}$ Annulla Linders \& Alana Van Gundy-Yoder, "Gall, Gallantry, and the Gallows: Capital Punishment and the Social Construction of Gender, 1840-1920." Gender and Society 22, no. 3 (June 2008): 327.

${ }^{98}$ Adler, "Homicide by Women," 897.
} 
to compare her circumstances to that of a battered wife at that place and time in history, as hers was clearly a shared experience by a great many Chicago murderesses. Sturla was one of 325 women who committed murder in Chicago between $1875-1920$, which accounted for $6.5 \%$ of all homicides in that period. Men obviously accounted for the vast majority of murders in the city at this time, but it is worth noting that women claimed more lives than Chicago policeman during the era. ${ }^{99}$ Women killed at only one-fifteenth the rate of men, most often killing relatives or suitors. Moreover, three-quarters of husband killers used firearms to slay their spouses. ${ }^{100}$ The overwhelming use of firearms indicates that battered women chose their murder weapon for its ability to largely make up for disadvantages in size and strength. In most of these cases, women bought or borrowed weapons, made post-murder arrangements, and openly planned to employ the unwritten law when they inevitably got to court. Women killers also seldom struck in public settings or expressed remorse. Husbands and lovers were often killed at home, many times while they slept. Women generally expressed relief and even occasionally expressed joy after ridding themselves of their abusers. ${ }^{101}$

Superficially, it would appear that Sturla followed the format for what Chicagoans would have expected of a woman murderer at the time. After all, she had murdered her lover with a revolver purchased just that morning, and witnesses heard her saying after the murder, "I came here to do this." ${ }^{\text {102 }}$ The prosecution used these facts as evidence to argue that Sturla's actions were premeditated and that she deserved to hang for them. As the story progressed, however, Chicagoans learned that the perpetrator of the Stiles murder broke the mold of their city's murderesses in a number of ways. For one, the Palmer House was (and still remains) one of the

\footnotetext{
${ }^{99}$ Adler, "Homicide by Women," 870.

${ }^{100}$ Adler, "Homicide by Women," 870, 879.

${ }^{101}$ Adler, "Homicide by Women," 870-82.

102 “The Stiles Murder Case," New York Times, December 10, 1882, 3.
} 
city's most popular high-end hotels; she could hardly have chosen a less private venue to commit a murder. Aside from the sensation of the crime occurring in such a heavily trafficked establishment, Sturla's reaction to the murder likely stood out to Chicago audiences. Her initial, remorseless comments aligned with the characteristics of typical women murderers at the time. However, as newspaper interviews and her legal defense indicated, she confessed that she still loved Stiles and never wanted to kill him, but she had to in order to save her own life. The shock and anguish Sturla expressed regarding her own crime throughout the trial likely went a long way in convincing the jury that she had not killed maliciously. Her actions were to be seen as a necessary solution to the terrifying problem of living with an abusive libertine. As the defense would argue, this solution was reached not by a woman of sound mind. Rather, Sturla's attorney claimed, her lover's physical and emotional treatment had exacerbated her dysmenorrhea, which ultimately caused a fit of maniacal fury that led to his demise.

On the national stage, a handful of dysmenorrhea-induced insanity cases had preceded Sturla's that emphasize the possibility of murderous women securing vindication: Mary Harris in 1865; Laura Fair in 1870; Fanny Hyde in 1872; and Lastencia Abarta in 1881—whose trial took place just a few months before Sturla murdered Stiles. The defense counsels for each of these women made a similar argument as Sturla's attorney. But in terms of an effort to successfully avoid the noose and attain moral vindication, Sturla was fighting an uphill battle from the moment she pulled the trigger. These four women were all certainly of the working class, but, as noted, Sturla was the only one who had fallen even before becoming involved with her paramour, making the possibility of being absolved in the eyes of society that much more difficult. $^{103}$

${ }^{103}$ Ireland, "Frenzied and Fallen Females." 
The most celebrated and significant of these cases was that of Mary Harris, a twenty-two year old woman from Chicago by way of Iowa who assassinated her former fiancé Adoniram J. Burroughs in January 1865. Burroughs had seduced Harris only to break off their engagement, desert her in Chicago, and leave for a job at the U.S. Department of the Treasury. This prompted Harris to follow Burroughs to the capital and shoot him in the back while he sat at his office desk. In her trial six months later, her lawyers relied heavily upon an insanity defense. They argued that Harris' temporary insanity was rooted in the tragic desertion she had experienced, but was compounded by her troubled menses. Harris' attorney went so far as to assert that Burroughs' breach of the promise of marriage to Harris represented "conduct...more injurious to morality than murder" and was therefore "worthy of the punishment of death..." ${ }^{\prime 104}$ Obvious premeditation on the part of Harris aside — significantly more so than in Sturla's case - the argument ultimately won an acquittal and established a precedent for Sturla's trial seventeen years later.

Although the jury had accepted the version of Victorian ethics presented by the Harris' lawyers, the New York Times interpreted the defense rather differently:

The verdict only furnishes a new illustration of what must be regarded as a settled principle in American law - that any woman who considers herself agrieved (sic) in any way by a member of the other sex, may kill him with impunity, and with an assured immunity from the prescribed penalties of the law. The man may really have been guilty neither of a crime against her person, an assault upon her honor, nor an offence against her feelings; if she is seized by a fancy that his course of

\footnotetext{
104 "Trial of Mary Harris for the Murder of Adoniram J. Burroughs, Washington D.C., 1865," Lawson, ed., American State Trials, 17: 233-373.
} 
conduct toward her is not such as she had anticipated from his addresses, she may kill him upon notice or without notice. ${ }^{105}$

The controversy stirred by Harris' acquittal did not exist solely in the media, but among circles of physicians recognized as eminent authorities on insanity as well. Dr. John P. Gray, editor of The American Journal of Insanity, wrote an article in that publication responding to the outcome of the Harris trial. Gray argued that Harris was not insane, but merely hysterically vengeful when she killed Burroughs. He admitted that "the sudden suppression of discharge [or] the puerperal state" might well be causes of mental disease, but "neither dysmenorrhea nor disappointed affection are of this class." 106

One of the nation's most renowned alienists, Dr. Isaac Ray, challenged this assertion in the article, "The Insanity of Women Produced by Desertion or Seduction," which was specifically written in support of the opinion in the Harris case. Ray asserted Mary Harris had been deserted, which was "the heaviest blow that a proud and sensitive woman could receive," resulting in a change of character to take place:

"[The] effects of the moral shock were intensified by a considerable degree of uterine derangement, and rendered somewhat periodical and paroxysmal in their manifestations. Her mind thus unsettled, and drifting about under the impulse of every morbid feeling, was finally led to contemplate the idea of murder, and, after accomplishing the act, to regard her conduct with no very definite sentiment of joy or of sorrow-with no realizing sense of the enormity of her crime or of its legal consequence to herself."107

\footnotetext{
105 "The Verdict in the Mary Harris Trial," The New York Times, July 20, 1865, 4.

${ }^{106}$ John P. Gray, “Trial of Mary Harris," The American Journal of Insanity 22 (January 1866), 259.

${ }^{107}$ Isaac Ray, "The Insanity of Women Produced by Seduction or Desertion," The American Journal of Insanity 23 (October 1866), 265.
} 
While some may have described the Harris case as a cautionary tale, the argument of insanity produced by difficult menstruation was apparently convincing enough for the medical community and society at large.

The disagreement between doctors Ray and Gray over the Harris case is representative of a larger debate that had been waging for decades among insanity experts. Throughout the first three decades of the century, medical literature reflected a growth of thought about insanity in Europe and the United States. French clinicians such as Philippe Pinel were some of the first to make real scientific efforts toward understanding mental diseases and the earliest American literature on insanity consisted mainly of summaries of French and British publications. Pinel's publication of Traité medicophilosophique sur l'alienation mentale ou la manie (Medicophilosphical treatise on mental alienation or mania) in 1801 represented the application of clinical empiricism to psychiatry, introducing ideas that were disseminated widely in the United States and Great Britain following its translation to English in 1806. Isaac Ray and other pioneer American alienists cited Pinel and his French followers, often using their own cases to corroborate the observations of their European counterparts. ${ }^{108}$

Pinel argued that dangerousness was one critical feature of certain types of insanity and believed it was necessary to recognize potentially dangerous lunatics and have a method of preventing harm. He classified forms of mental derangement as defects of the intellect, the passions, and the will. Derangement of the intellect was termed "Melancholia," represented in patients who were "deluded and dangerous beings who can commit most barbarous homicides in cold blood." In some cases a lunatic exhibited no defect in intellect, but was prone to fits of

\footnotetext{
108 Janet Colaizzi, Homicidal Insanity, 1800-1985 (Tuscaloosa: The University of Alabama Press, 1989), $13-14$
} 
maniacal fury, a condition Pinel referred to as "mania without delirium." ${ }^{109}$ These patients were considered the most dangerous because they did not exhibit intellectual derangement and were largely unpredictable. One area in which not all physicians accepted Pinel's authority was in the relationship between reason and responsibility. Pinel contended that some lunatics could reason logically and yet were unable to control the passions or the will. ${ }^{110}$

American physician Theodric Romeyn Beck relied on Pinel's ideas about medical care and moral treatment of insane persons, arguing in 1811 that involuntary commitment of lunatics was necessary for the security of the public and for proper treatment of the patient. While Beck did not presume that all lunatics were dangerous, he did believe they were "all more or less liable" to commit crimes for which they could not be held responsible. ${ }^{111}$ Celebrated civic leader, politician, and physician Benjamin Rush was one of the first American medical men to specifically cite impairment of moral faculties as a symptom of insanity. Although dangerousness was not an overt theme in his Medical Inquiries and Observations upon the Diseases of the Mind (1812), he did predict the potential for dangerousness in cases of a condition he called manalgia, one form of "general intellectual derangement." According to Rush, manalgia caused moral faculties to become impaired and made patients mischievous or vicious. Rush also considered murder and theft as derangement of the will: "When the will becomes the involuntary vehicle of vicious actions, through the instrumentality of the passions, I have called it Moral Derangement." Emphasizing a growing attitude of the medical establishment's absolute authority, Rush declared that the crimes of murder and theft were symptoms of disease and that they should be "rescued" from the law by "the kind and lenient

\footnotetext{
${ }^{109}$ Philippe Pinel, A Treatise on Insanity. Trans. D.D. Davis. (London, 1806), 142-152.

${ }^{110}$ Colaizzi, Homicidal Insanity, 16.

111 Theodric Romeyn Beck, Inaugural Dissertation on Insanity, (New York, 1811), 28.
} 
hand of medicine." ${ }^{112}$ In spite of corroboration by other clinicians in years to follow, the ideas of "partial" and "moral" insanity were controversial well into the twentieth century. This was certainly true in the early part of the nineteenth century, as the notion that a person could behave normally and yet have thoughts and feelings that might overpower logic and reason defied the Enlightenment way of thinking. ${ }^{113}$

The first alienist to identify "moral insanity" as a distinct illness was British physician James Cowles Prichard in 1835. According to Prichard, the critical feature of the phenomenon was that feelings were not controlled by the intellect: "The sudden anger of a person laboring under moral insanity, and subject to paroxysms of rage...[was] an immediate impulse arising spontaneously on the mind, which was diseased only in its moral constitution." ${ }^{.114}$ Isaac Ray, who became one of the most important figures in nineteenth century forensic psychiatry, agreed with Prichard's ideas that corruption of moral faculties could occur in the presence of adequate intelligence. Ray expanded on Prichard's work by introducing a framework that declared there were multiple moral faculties, and the degree of dangerousness in the morally insane person depended upon which of these faculties was involved in the pathology. ${ }^{115}$

While Ray's early work was significant as a synthesis of prevailing ideas about insanity in France and England at the time, it also reflects the inconsistencies of disease classification and the failure of physicians to reach an agreement about basic issues in medical jurisprudence. Experts generally agreed on the concepts of partial insanity but speculated over whether the intellect could remain intact in any cases of insanity. Alienists were also divided in their efforts

\footnotetext{
${ }^{112}$ Benjamin Rush, Medical Inquiries and Observations upon the Diseases of the Mind, $2^{\text {nd }}$ ed. (Philadelphia, 1818), 181-183.

${ }_{113}$ Colaizzi, Homicidal Insanity, 17-18.

${ }^{114}$ James Cowles Prichard, A Treatise on Insanity and Other Disorders Affecting the Mind (London, 1835), 112.

${ }^{115}$ Colaizzi, Homicidal Insanity, 27-29.
} 
to legally differentiate between the homicidal insane and the mere criminal. Some physicians judged insane persons qualitatively, believing that insanity was limited to individual mental faculties. Others made quantitative assessments, considering insanity in terms of degree rather than kind. ${ }^{116}$ Conflicting methods of determining dangerousness highlighted the medical establishment's inability to reach a theoretical consensus, which propelled the belief among some alienists that no legal test for insanity existed.

The issue of insanity among women was an additional source of tension for medical men. Hysteria and insanity induced by dysmenorrhea — both disorders that Theresa Sturla allegedly exhibited - represented methods of control over Victorian female behavior. While hysteria and insanity were not technically diseases reserved for women, nineteenth century physicians reported that urban women between the ages of fifteen and forty and of the middle and upperclasses were affected far more often than men. The male medical community's ambivalence toward women patients was especially true in cases of hysteria, mirroring the hostile view of hysterical women held by a significant portion of society that was enforced by cultural and social norms. Carroll Smith-Rosenberg has argued that this resentment in the minds of physicians emanated from the relation between their categorizing of hysteria as a disease and the social role of women. For them, a hysterical woman was a biologically and socially dysfunctional woman who threatened physicians both as professionals and as rejected men. According to SmithRosenberg, the physician of a hysterical woman "was the therapist thwarted, the child untended, the husband denied nurturance and sex." 117

While the medical community argued amongst themselves, they also clashed with legal professionals in the courtroom. Conflicting theories of deviance between the two professions was

\footnotetext{
${ }^{116}$ Colaizzi, Homicidal Insanity, 40-41.

${ }^{117}$ Smith-Rosenberg, "The Hysterical Woman" in Disorderly Conduct, 198-202.
} 
sparked by an attempt made by medical men to formally reinterpret the concept of human responsibility. The traditional, Enlightenment way of determining deviance was through the concept of free will. American law assumed that individuals were free agents capable of distinguishing right from wrong. If a defendant lacked the fundamental ability to tell whether his or her actions were wrong, they would be excused from responsibility. Conversely, medical theorists held a deterministic view of human behavior that was rooted in biology. Rather than the agents of free will the law supposed individuals to be, proponents of the naturalistic medical model —Isaac Ray included — viewed people as organisms subject to physical derangement. As John Starrett Hughes observed in his extensive study of Ray's work, the conflict between the medical and legal establishments represented a foundational difference in opinion of law's importance in the community. ${ }^{118}$ It is in this context, then, that Theresa Sturla first took her seat in the Criminal Court of Cook County on November 21, 1882.

In many ways, Theresa Sturla's trial follows the formula of nineteenth century unwritten law cases extremely closely. In his opening statement, the prosecuting attorney, L.L. Mills, argued Sturla "was not, and is not insane," and that "her every act indicated deliberation." He warned the jury not to be "diverted by any sentimentality" merely because there was a woman on trial. ${ }^{119}$ Theresa's attorney, A.S. Trude, contrasted Mills' depiction of his client with a dramatic flourish, telling the court that the entire history of Sturla and Stiles' relationship was "written in tears and blood—her tears and her blood." ${ }^{120}$ He explained how Stiles had "gained complete control of the Italian girl" in Baltimore, and established the victim's character and pattern of abusive behavior toward Sturla. He then explained that she was the victim of a medical condition called dysmenorrhea:

\footnotetext{
${ }^{118}$ Hughes, In the Law's Darkness, xiv-xvi.

${ }^{119}$ Trial transcripts, as quoted in Turner, Sturla-Stiles Tragedy, 89-90.

${ }^{120}$ Trial transcripts, as quoted in Turner, Sturla-Stiles Tragedy, 90. Italics in original.
} 
From the time she emerged from girlhood into womanhood, she has been the victim of suppressed or difficult menstruation, the seriousness of her condition was intensified by the brutal treatment she endured at the hands of Stiles, and from the periods when she has her menses, she is deranged. When he adds fresh acts of brutality upon her when she is menstruating, she is wildly insane.

Trude concluded his opening statement by explaining that he would bring to the stand character witnesses who were "well known and reputable persons," ultimately showing "acts of brutality, which [are] a predisposing cause of insanity, from the time of the last mentioned act up to about July $5^{\text {th }}, 1882$, by police officers, citizens and carriage drivers." ${ }^{121}$

True to form for unwritten law cases, the defense introduced a host of lay witnesses who confidently declared that they believed Sturla to have been insane when she killed Stiles, most of whom recounted instances of the defendant in conditions of high agitation. ${ }^{122}$ Rosa Ashton, a housekeeper in the building where Sturla and Stiles kept an apartment together, described Sturla's behavior on the occasions she had her "monthly sickness." She said that when Sturla "had her 'monthlies' and had trouble with [Charlie] besides, she was always in great pain and was not right in the head." 123 The matron of the Cook County jail, Augusta Papendeick, had observed the defendant for several months at that point and described some of Sturla's unusual behavior: "[Sturla] would kneel down after surrounding herself with candles and pray; then she would suddenly jump up and sing, then laugh and as suddenly cry. At other times she would take [Stiles'] picture and say she would like to...dig up his bones and have them near to her." Papendeick also claimed that "at times her face looked unnatural, and the pupils of her eyes were

\footnotetext{
${ }^{121}$ Trial transcripts, as quoted in Turner, Sturla-Stiles Tragedy, 90-95.

${ }^{122}$ Robert Ireland, "Insanity and the Unwritten Law," The American Journal of Legal History 32, no. 2 (April 1988), 161.

${ }^{123}$ Trial transcripts, as quoted in Turner, Sturla-Stiles Tragedy, 113.
} 
dilated." Upon cross-examination by the prosecution, she said with authority she did not "think that [Sturla was] pretending or following out a line of defense marked by her attorney."

Other witnesses attested to the abusive nature of the relationship, an important factor in the formula that led to Sturla's alleged insanity. Frederick E. Davis said that he spoke with Stiles at Downing's the day before the murder when the couple were there having dinner. Davis confronted Stiles and told him that he heard he "treat[ed] her badly." To this Stiles replied, "The more I thump her the better she likes me." ${ }^{\prime 25}$ William A. Pinkerton of the Pinkerton Detective Agency testified as to what he observed two years prior to the murder. After a particularly heated fight, Sturla had a basket "consisting of layers of rotten potatoes, decayed cabbages, old onions, set off on the top by a large beet marked 'Charles Stiles"' sent to the Board of Trade while he was working. Stiles was so embarrassed and enraged by this that he hired the Pinkertons to confront Sturla "to induce her to let him alone in the future." After hearing about the abuse that she regularly endured, Pinkerton suggested she might leave Stiles with the aid of the police. A few weeks later Pinkerton checked up on Sturla at her home and was surprised to find that Stiles was still there. During that visit, Stiles attempted to strike Sturla with a water pitcher but was stopped by Pinkerton. Sturla "acted unnatural" and told the detective "Charlie had hoodooed her." She talked about destiny and fate bringing them together, to which Pinkerton retorted, "Destiny and fate would separate them with a bloody hand."126

One of the most damning of the character witness testimonies came from Miss Carrie Watson, madam of the popular brothel where Stiles had forced Theresa to work during periods in which he was especially low on cash. Stiles first brought Theresa to her house about two and a half years prior to the murder. One evening, Watson said, Stiles drunkenly broke through the

\footnotetext{
${ }^{124}$ Trial transcripts, as quoted in Turner, Sturla-Stiles Tragedy, 116.

${ }^{125}$ Trial transcripts, as quoted in Turner, Sturla-Stiles Tragedy, 114.

${ }^{126}$ Trial transcripts, as quoted in Turner, Sturla-Stiles Tragedy, 111-12.
} 
door of Sturla's room and "got into a scuffle, when he fell down the stairs." Another time, Watson caught Stiles hiding in a closet, waiting for Theresa to give him the money she made that day. Finally, she confirmed for the court that when Sturla "had her 'monthlies' and was vexed at something Charlie did to her, she was very bad and seemed out of her mind." 127

Over the course of the nearly three week trial, thirteen reputable physicians known to be experts on insanity enhanced these lay witness testimonies. These expert witnesses served to provide medical theories that would corroborate the behavior of the defendant as insane, supporting theoretical pronouncements with specific and impressive symptoms of insanity. ${ }^{128}$ This practice had become the norm for trials in which the defendant's sanity was in question, giving the medical community an active role in jurisprudence. The existence of "experts" on insanity was a new phenomenon in and of itself: it was only recently that the insane, once chained and hidden from view, were unbound and placed in special hospitals run by doctors dedicated to studying their disease. As the leading alienist of the day, Dr. Isaac Ray led the charge in attempting to define the role of doctors in the courtroom, bringing scientific values to the law that often challenged the values of legal professionals. While lawyers looked backward by celebrating precedent, doctors tended to look forward to utilizing the progression of science to solve legal matters. ${ }^{129}$

The first physician to take the stand was Dr. James H. Bates, who had had Theresa as a patient for three years at that point. He treated her once when Stiles had knocked her tooth out and another occasion when she had been kicked in the side. Bates claimed that Sturla's "excitement was variable, severe when she claimed to have been mistreated just before, often

\footnotetext{
${ }^{127}$ Trial transcripts, as quoted in Turner, Sturla-Stiles Tragedy, 118-19.

${ }^{128}$ Ireland, "Insanity and the Unwritten Law," 160.

${ }^{129}$ John Starrett Hughes, In the Law's Darkness: Isaac Ray and the Medical Jurisprudence of Insanity in Nineteenth-Century America, (New York: Oceana 1986), xii-xvi.
} 
almost delirious...There were all the conditions present that might produce homicidal mania." On the day of the murder, Bates had examined Sturla at the police station after her arrest and confirmed that "she was sick—-had her menses...[and] must have had them the night before." Considering the circumstances around the murder, Bates said, "All things that she suffered are predisposing causes of insanity, and when all those causes were combined in one person, and that person a woman, sanity would be the exception and insanity the rule. ${ }^{1130}$ As the court would see, Bates was the first of many doctors to apply common medical conceptions of femininity and female biology to Theresa Sturla.

Although medical and biological justification for the roles assigned to women was nothing new at this point in history, it took on a new form in the nineteenth century as the intellectual and emotional supremacy of science increased. Scientific arguments were used in nearly all aspects of Victorian life, but especially in areas in which it might challenge social arrangements and affect social change. ${ }^{131}$ Medical orthodoxy of the time insisted that women were starkly different than the male of the species. In a physical sense, women were more frail and delicate. More significantly, the female nervous system was inherently more irritable than that of the male, prone to overstimulation and exhaustion. Physicians also saw women as prisoners of their reproductive systems, which dictated her social role and behavior from puberty through menopause. ${ }^{132}$ As George Man Burrows wrote in 1828, even those doctors "of the least experience" should be aware of the influence that menstruation has on the mind, and recognize it as the "moral and physical barometer of the female constitution." ${ }^{133}$ It is little wonder, in the eyes

\footnotetext{
${ }^{130}$ Trial transcripts, as quoted in Turner, Sturla-Stiles Tragedy, 120-22.

${ }^{131}$ Carroll Smith-Rosenberg and Charles Rosenberg, "The Female Animal: Medical and Biological Views of Woman and Her Role in Nineteenth-Century America," The Journal of American History 60, no. 2 (September 1973), 332; Russet, Sexual Science; Lander, Images of Bleeding.

${ }^{132}$ Smith-Rosenberg \& Rosenberg, "The Female Animal," 334-5.

${ }^{133}$ George Man Burrows, Commentaries on Insanity (London: Underwood, 1828), 146.
} 
of contemporary observers, that a woman like Sturla would be unable to distinguish morality from deviance.

On the day following Bates' testimony when another doctor-Thomas Schmidt—was on the stand, Sturla's attorney put forth a long-winded "hypothetical" question. The question amounted to a summary of the abuse his client had endured over the course of the last five years and a description of the events that had transpired the night before the murder, culminating in the death of Stiles on July 10. Trude concluded his question by asking Dr. Schmidt if he would consider Sturla legally insane or not when she fired the shot. ${ }^{134}$ "I should certainly consider her insane," Schmidt replied. "It is impossible for a woman to be in the condition described and not be mentally affected. Not only that, but the very fact that a woman should subject herself to the brutalities named, so long, I should regard as a very strong addition of proof." ${ }^{135}$ Later the same day, Dr. Daniel R. Bower, the former superintendent of an insane asylum in Illinois, confirmed for Trude that brutality inflicted for five years is certainly a predisposing cause of insanity among women. Upon being asked if he had ever had any cases that he treated with regard to menstrual difficulty, Bower answered:

A young lady patient has to be constantly watched upon every occasion of her periods, for fear that she will commit homicide. The relations that the sexual organs bear to the home of thought - the brain - is very close and intimate, and when it is shown that this young woman had this disease, dysmenorrhea, and was menstruating on the night of July $9^{\text {th }}$ when in an excitable frame of mind...she would be a wonder if she preserved her equilibrium. ${ }^{136}$

\footnotetext{
${ }^{134}$ Turner, Sturla-Stiles Tragedy, 125-40.

135 Trial transcripts, as quoted in Turner, Sturla-Stiles Tragedy, 140.

${ }^{136}$ Trial transcripts, as quoted in Turner, Sturla-Stiles Tragedy, 171.
} 
Dr. Henry Lyman confirmed that "disorders of sexual organs are frequent causes of insanity in women," and that he had "never read so severe a case of hysterics as that shown in this case."137

On day twelve, Theresa Sturla took the witness stand to give her testimony. Throughout her trial Sturla had been somber, clad in a black dress and a veil that obscured her face, exposing only small curls of dark hair-her "widow's locks." ${ }^{\text {"138 }}$ As she sat facing the audience in the court for the first time, her face was pale and her forehead "slightly wrinkled with a frown of thoughtfulness or pain." She held a white handkerchief that she frequently applied to her eyes and nervously twirled in her fingers. "With every eye in the court-room on her, and every ear intent on each syllable, she began the story of her sufferings." ${ }^{139}$ Sturla proceeded to regale the court with the origins of her relationship with Stiles and over a dozen instances of the physical and emotional abuse she had suffered. A number of Sturla's vignettes involved Stiles requesting money and threatening her when she would not give it to him. On one such occasion, Sturla had refused to give Stiles the $\$ 350$ she made from selling furniture from her old apartment:

It was nighttime and we stood on the railing of [a] boat, and he said that he had a good notion to throw me into the river. I said that would be murder and he would be hung. He said it was not murder to kill a prostitute; that there was no law for them, and that it was no crime to kill one. I took out my pistol and told him to keep away, which he did. On our way home we made up and I went back to Watson's. He began coming to the house drunk. ${ }^{140}$

\footnotetext{
${ }^{137}$ Trial transcripts, as quoted in Turner, Sturla-Stiles Tragedy, 173.

${ }^{138}$ Turner, Sturla-Stiles Tragedy, 143.

${ }^{139}$ Trial transcripts, as quoted in Turner, Sturla-Stiles Tragedy, 143.

${ }^{140}$ Trial transcripts, as quoted in Turner, Sturla-Stiles Tragedy, 162.
} 
A particularly sensational climax of the testimony came when Sturla recounted the events of July 9 and 10. According the Chicago Times, she began to sob and got "wilder and wilder at every word," evidently making an emotional appeal to many in attendance:

During these last words of her testimony, when her heart seemed breaking and the spectators were all shading their eyes, Mr. Trude, the attorney for the defense, rose from his seat, and withdrawing from where the jury could see his face, he stood dazed, the tears rolling down his cheeks and his lips quivering with sympathetic emotion. He was not the only one. There was many a strong man doing the same. ${ }^{141}$

As she described the moments before the murder, Theresa's face was in her hands, her breast heaved, and violent sobs broke between her words. She cried, "I killed him!" and suddenly went into a frenzy. According to the Chicago Times reporter present, "She rose spasmodically from her seat, clutched the air and fell to the floor...scream after scream came from her throat, and four bailiffs rushed to her. These four strong men were powerless to control that girlish form as she struggled and tore at her breast." Sturla was forcibly removed from the courtroom while "she gnashed her teeth and bit at her captors, until partially exhausted from her frenzied efforts and screams. ${ }^{142}$ Dr. A. Reeves Jackson—whom the prosecution had called earlier as a witness against Sturla—examined her after she was removed from court, confirming that she had "suffered from a very pronounced attack of hysteria" and refuted insinuations that she had been feigning.

Records show that two of the twelve jurors at Sturla's trial had openly expressed biases against the defendant during the jury selection process, having stated they were for conviction

\footnotetext{
${ }^{141}$ Trial transcripts, as quoted in Turner, Sturla-Stiles Tragedy, 166-67.

${ }^{142}$ Trial transcripts, as quoted in Turner, Sturla-Stiles Tragedy, 167.
} 
and capital punishment. A.S. Trude attempted to get these two jurors excluded from the jury on the third day of the trial but the Court declined, ruling that the jurors had been accepted and sworn in and could not be excused. ${ }^{143}$ On the morning of December 18 in a packed courtroom, the jury returned with a compromised verdict finding Sturla guilty of manslaughter with a oneyear prison term, "the lowest known to law," according to Judge George Gardner. Given the precedent set by Mary Harris and the course of events during trial, it is reasonable to assume that Sturla would have walked out of the courthouse a free woman had the biased jurors been excused as per Trude's request. Although it was not an acquittal, Theresa listened to the verdict with a smile on her face and with an "ironical accent and contemptuous curl of the lips," she addressed the court, thanking the efforts of the judge, jury, and her attorney. ${ }^{144}$ As the Times reported, "When the Court concluded she with an elastic step went back to jail.",145

In unwritten law cases in which insanity was a central issue, the prosecution and defense sometimes disputed which side had the burden of proof. In Sturla's case, Judge Gardner's instructions fall in line with those of most judges in his position, who generally ruled that defendants were presumed sane in the eyes of the law. Therefore, the burden of proof was on the defense, but the jury must acquit if the defendant's proof created reasonable doubt of his or her sanity. Since the defense could rather easily create uncertainty by calling witnesses to verify alleged insanity, judges instructed juries that they had to believe beyond a reasonable doubt that the defendant was sane at the time of the murder in order to render a verdict of guilty. This instruction that typically benefitted the defendant, especially when coupled with permissive definitions of insanity. ${ }^{146}$

\footnotetext{
${ }^{143}$ Turner, Sturla-Stiles Tragedy, 227.

144 “Theresa Sturla," Chicago Daily Tribune, December 24, 1882, 9.

${ }^{145}$ Chicago Times, December 24, 1882, as quoted in Turner, Sturla-Stiles Tragedy, 228.

${ }^{146}$ Ireland, "Insanity and the Unwritten Law," 171.
} 
What is most striking about Gardner's instructions is that he effectively eliminated insanity from the overall defense, instructing the jury, "What constitutes legal insanity is a question purely of law and fact and in determining this question the jury are not to be governed by the opinion of any medical expert, but are to decide the case according to the law of this state and the evidence in the case. ${ }^{, 147}$ With these directives, the jury was to view the case strictly from a self-defense standpoint. Moreover, Gardner completely shut down the biological deterministic view of crime that physicians had brought to his courtroom. In this way, he reinforced the traditional attitude held by American legal professionals that revolved around free will. As the following chapter will show, this did not necessarily hurt Sturla's chances of avoiding capital punishment. Rather, her attorney adopted rhetoric of moral reform in order to exonerate his client.

${ }^{147}$ People of the State of Illinois versus Theresa Sturla, alias etc., (July 1882). 


\section{CHAPTER III: “GO THOU AND SIN NO MORE”}

Despite any complications biased jurors may have caused during the deliberations, the jury had decided Theresa Sturla was not the monster the prosecution had made her out to be and was deserving of an opportunity for redemption. The question is, what exactly gave them this impression? Sturla's morality as it pertained to her womanhood became the main problem to be dealt with during the trial. Chicagoans devoured the sensationalism of an insanity plea but even that defense boiled down to a question of morals when the defense introduced the idea of moral insanity. This was problematic itself because physicians could not reach a consensus as to what exactly constituted temporary insanity or moral insanity. Remarkably, the insanity plea itself became a secondary issue behind morality, which was much more fiercely debated toward the end of trial and for the duration of Sturla's prison sentence. While the jury and the public may not have been sure if the defendant was legitimately insane, they could certainly judge her moral fortitude and watched closely to see if this fallen murderess was actually capable of redeeming herself. Chicagoans were also reacting to growing concerns over the relationship between vice and class in the city, fearing that the pervasiveness of prostitution would destroy middle-class life and values. The public conversation around Theresa Sturla as a woman and as a murderer offers an example of the crisis of class and morals in Chicago that would lead to massive municipal reform within a few short decades.

As events transpired in the courtroom, the public questioned Sturla's inherent morality during the trial and continued to do so throughout her eleven months in prison. From the beginning of her trial, newspaper accounts constantly speculated two things about Theresa Sturla: whether or not she was insane; and whether or not she was capable of redemption if she was not convicted. Comments from the public and from reporters regarding the issue of insanity 
generally mirrored what the physician witnesses discussed in court. The issue of redemption, however, was much more hotly debated. This fire was fueled by public support Sturla received from two very different well-known Chicago women, one of whom embodied vice, the other virtue. The support from Madame Carrie Watson and ardent reformer Mrs. Hortensia Black brought the debate over Sturla's predisposition for virtue to the forefront of the public conversation for over a year, until she was released from prison in November 1883. By this time, it had become increasingly common for middle and upper class female moral reformers to cross class lines in order to fight for their fallen sisters.

As early as the day after the murder, Chicago newspapers reported that Carrie Watson, Sturla's employer and the operator of one of the city's most popular upscale brothels, regularly visited Sturla in jail and was one of her closest friends in the wake of the murder. Writing in 1894, British journalist and social reformer W.T. Stead referred to Watson as the best-known Madame in Chicago, who could charge top dollar as she was "at the head of her shameful profession. ${ }^{148}$ Watson was well known in 1882, but became even more notorious in later years. For several years toward the end of the century, Watson hosted an annual party branded as a “benefit” for Lame Jimmy, the Madame's house violinist. These extravagant, bacchanalian affairs were attended by a mixture of the demi-monde and businessmen and politicians who were friendly to the vice districts. Watson's yearly benefit ended in 1894 when, during the festivities, "one of the best known police officers in Chicago was shot dead in the midst of the orgy."149

\footnotetext{
${ }^{148}$ William T. Stead, If Christ Came to Chicago!, (London: The Review of Reviews, 1894), 237-239. Stead's book was a reaction to his first visit to Chicago, in which he addressed what he considered to be rampant vice and immoral behavior on the part of its citizens. Working with other moral reformers in the city, the book paved the way for the formation of the Chicago Vice Commission and the closure of Chicago's Levee district.

${ }^{149}$ Stead, If Christ Came to Chicago!, 239.
} 
Carrie Watson's presence was very likely a great personal comfort to Sturla, but she also aided the murderess when she preemptively bolstered the defense by informing reporters that Stiles had "shamefully abused" his mistress and "made her life miserable in many other ways." In one interview, she confirmed that Sturla regularly carried a pistol in her pocket but did not believe she had intended to use it on Stiles that morning. ${ }^{150}$ Not only did Carrie Watson aid Sturla with moral support, she was also responsible for funding the defense. The Chicago Times reported that the "fallen angels on the "Levee"" had made a heroine of the murderess. ${ }^{151}$ Watson had begun raising funds for Sturla's benefit by putting up $\$ 500$ of her own money, which was soon matched by donations from other working girls. According to the report: "Among the demimonde the murder is still the all-absorbing theme of conversation. The women of the town discuss the details of the tragedy and relate incidents in connection with the lives of the victim and his murderess with morbid pleasure."152

Shortly after the trial, newspapers reported that when Sturla was arrested, she took somebody's suggestion of sending for A.S. Trude, "the most successful lawyer in the city." She told him she had no money but was in need of legal advice. Hearing her situation, he offered his services pro-bono. There would be other costs, however, and Carrie Watson ultimately put up $\$ 2,000$ of her own money toward the defense. Sturla had the sympathy of other women "of her class," who also contributed to the defense fund "until there was about $\$ 900$ to supplement the $\$ 2000$ of Mme. Watson.” All of this money was used to defray the costs of reimbursing witnesses for their travel and time and to hire a stenographer. ${ }^{153}$

\footnotetext{
${ }^{150}$ Turner, Sturla-Stiles Tragedy, 43-44.

151 The "Levee" refers to Chicago's most infamous red-light district, which encompassed four blocks in today's South Loop. Along with the infamous Everleigh Club, the Levee District was home to Carrie Watson's brothel and the house that Sturla operated for a brief time.

152 "Sisters in Sin," Chicago Times, July 13, 1882, as cited in Turner.

153 "Tried for Her Life," Milwaukee Journal Sentinal, Dec. 17, 1882, 7.
} 
While the Stiles murder may have been a cathartic moment for the city's fallen women, their involvement in the matter inspired distrust toward the murderess. Some newspapers speculated that her account of the events leading up to the murder were not to be trusted. A Chicago Times editorial attacking Sturla entitled "Rampant Harlotry" said that "since the awful deed the fallen women have come out on the streets in force...they appear in bright colors and seem to feel triumphant over the matter." ${ }^{154}$ Had this piece not been printed the murderess may never have gained a crucial ally, who would come to represent her propensity for virtue and redemption.

Hortensia Black responded to the editorial, appalled at the unfair attack on Sturla and "[felt] called on to enter the lists in behalf of one who can not speak for herself." Mrs. Black was the wife of W.P. Black, a prominent lawyer in Chicago who was best known for serving as defense council for the men accused of inciting the Haymarket Riot in 1886. The couple was well known for their involvement in the local temperance movement and other social reform activities. Mrs. Black was particularly vocal as a believer in faith healing and as a vegetarian and fierce advocate for animal welfare. An 1899 Tribune piece featuring Mrs. Black’s animal activism explained that she was a "reincarnationist" who believed that human souls pass on to animals after death. ${ }^{155}$

In response to the article that attacked Sturla, Mrs. Black wrote a letter to the editor of the Times defending the womanhood of Sturla and her fallen sisters and blaming men for such tragic incidents. Mrs. Black declared that men had made women "cold and hard, and suspicious, and jealous" and they would not let men "mold [their] thoughts and opinions any more." Horrified by the idea that a man would bet and pay bills on the earnings of a woman's body, Mrs. Black

\footnotetext{
${ }^{154}$ Quoted in Turner, Sturla-Stiles Tragedy, 74.

155 "Faith Healing," Chicago Daily Tribune, March 13, 1886, 13; "Brutes Held By Love," Chicago Daily Tribune, March 12, 1899, 30.
} 
posited "the young woman did the natural, if not the right, thing when she shot her oppressor." She went so far as to say that if Sturla were to be tried by a jury of women, they "would not be long in rendering our verdict" and "would desire, with feminine irrelevancy to tack on to [the] verdict some kind of provision for her." ${ }^{, 156}$ Mrs. Black placed more blame on Stiles' mother than she did Stiles himself, attacking her womanhood and questioning why she did not raise him better and why tears were "not shed over his sinning life instead of his, as it seems to an outsider, very fitting end." ${ }^{157}$ It was the woman sitting in a jail cell, not her dead lover and his family who deserved to be pitied:

"She may have callers and champagne, but oh! What has she beside? Remorse and the spectre of her dead unworthy love; an empty, hopeless life; the doors shut before and behind her; never a husband's honoring touch, never the tender caress of a baby hand, none of life's sweet and sacred cares! Shut out! Outcast!"158

After Mrs. Black's letter was printed in the Times, she became a regular visitor of Sturla's during her time in jail. Reports circulated that she had vowed to take Theresa under her wing and do what she could to help her pursue her dreams of singing on stage. Mrs. Black and Carrie Watson each sat at the defendant's side throughout the trial.

This was not the first time a dysmenorrheal insanity case incited support from women who had never met the defendant, as a similar situation had arisen during the Mary Harris trial thirty years prior. After her arrest in Washington, Harris had little money and no friends or family for hundreds of miles. Luckily, newspaper accounts of her story made an impression on other women. A few local Washington women volunteered to run errands for Harris, while a pair

\footnotetext{
${ }^{156}$ Turner, Sturla-Stiles Tragedy, 75.

${ }^{157}$ Turner, Sturla-Stiles Tragedy, 76.

${ }^{158}$ Quoted in Turner, Sturla-Stiles Tragedy, 77.
} 
of sisters and some friends traveled from Wisconsin to testify on her behalf. ${ }^{159}$ Sturla's situation was different, though. Mrs. Black’s involvement did not merely represent one woman’s sympathy for the defendant. When she was called as a character witness, Mrs. Black explained that she had taken an interest in Theresa "on account of her very sorrowful life," and that her deportment was "singularly womanly, modest, and gentle." With these words, Black granted Sturla sympathy based on her conformity to the ideals of true womanhood. Apparently she also had a close personal connection to the defense itself: "I lost one very dear person from dysmenorrhea. Another became incurably insane from the same cause. Another was only so every month. The case was very pitiful and sad, and she was a very lovely woman, but at such times she could not control herself." The fact that an upper class, respectable woman saw the capacity for virtue in the heart of an Italian prostitute almost certainly affected the perception the public and jury had toward her. This sentiment was reinforced by Sturla's declarations that when she was free, she planned go to live with Mrs. Black and study music. "When I can make an honest living with my music or any other way" she vowed after she was sentenced, "I will try to do it, but I will never go back to my old kind of life again. ${ }^{, 160}$ Mrs. Black's relationship with Sturla exemplifies the attitudinal changes toward the redemption of prostitutes that occurred in the nineteenth century.

The Victorian code, firmly planted in middle class values, dictated that women who abandoned virtue had no place in society. These women were often cast not as fallen angels capable of redeeming their virtue, but rather evil temptresses or sirens of vice. ${ }^{161}$ These sentiments were perpetuated by regulations and criminal sanctions that condemned prostitutes.

\footnotetext{
${ }^{159}$ Carlson, The Crimes of Womanhood, 44.

160 "Nerved for the Verdict," Chicago Daily Tribune, Dec. 17, 1882, 6.

${ }^{161}$ Barbara Meil Hobson, Uneasy Virtue: The Politics of Prostitution and the American Reform Tradition (New York: Basic Books, 1987), 70-75.
} 
Despite obvious male involvement in the exchange of money for sex, courts ruled that prostitution was a female offense. This helped in codifying the notion that female, but not male, promiscuity was tied to delinquency. ${ }^{162}$ When prostitution was becoming more visible in American urban centers in the early part of the nineteenth century, most complaints about the illicit sex trade arose on the grounds that it was a public nuisance.

However, as Christian ministers and missionaries encountered prostitutes during outreach efforts, they were often moved to help the women and gradually equated prostitution to a problem of immorality. The first organized effort to reform fallen women was the Magdalen Society of New York, inspired by the work of Presbyterian minister Ezra Stiles Ely. ${ }^{163}$ Ely used sympathetic portrayals of prostitutes to change perceptions of fallen women and to persuade Christians to help rescue women from their lives of sin. In 1812, the Magdalen Society of New York established an asylum for penitent prostitutes that would afford them protection and support while they received religious, moral, and practical training that would give them the necessary tools for successful reformation. The ultimate hope of the society was for women to leave the asylum and reunite with family and friends or secure respectable employment. ${ }^{164}$ Despite their best efforts, the Magdalen Society of New York only received a small number of "penitent prostitutes" in their asylum. Many women ended up running away or being dismissed and only a few were successfully reclaimed. In 1818, the asylum was closed, and the society ceased all operations. At the time, a number of missions, ministries, and benevolent societies existed that could offer assistance to fallen women, but none focused specifically on dealing with

\footnotetext{
${ }^{162}$ Hobson, Uneasy Virtue, 35.

${ }^{163}$ Shaver, Reforming Women: The Rhetorical Tactics of the American Female Moral Reform Society 1834-1854 (Pittsburgh: University of Pittsburgh Press, 2018), 23.

${ }^{164}$ Shaver, Reforming Women, 24-25.
} 
prostitution directly. Nevertheless, the seed had been planted for private citizens to take up the fight for moral reform. ${ }^{165}$

In the 1830 s and 1840 s, evangelical women in moral reform societies began to transform the social and political conversation around prostitution. Rather than place the blame on innocent women and punish them for "choosing" a life of vice, female moral reformers constructed new sexual politics around prostitution. They declared that prostitution was a by-product of male dominance in economic, political, and social life, and viewed the sexual double standard as an extension of the power imbalance between the sexes. By analyzing prostitution in the context of sexual exploitation, female moral reformers argued that prostitution was a result of male sexual aggressiveness and an expression of class and gender inequalities. ${ }^{166}$

Christian female moral reformers in this way developed a gendered rhetoric that bound women together by their shared experiences and fostered a sisterhood centered on gender rather than class. In the effort to protect their sex, they argued that women had to align and force men to adopt the same codes of behavior that were applied to women. It is important to note that, while much of their rhetoric might be viewed as a precursor of modern feminism, these women did not identify as feminists. Although they placed the burden of responsibility for the double standard on men, they did not presume that women should take over or even share the sources of power in the legal, economic, and political arenas in which men dominated. ${ }^{167}$ Instead, they used the ideology of domesticity and assumptions of human sexuality to bolster their efforts. They accepted that women and men had different mental, moral, and sexual natures and therefore had different spheres of influence. A woman's role was to be the supportive, chaste, self-sacrificing wife and mother bound by religion and the home. In those spheres her power should dominate all

\footnotetext{
${ }^{165}$ Shaver, Reforming Women, 27.

${ }^{166}$ Hobson, Uneasy Virtue, 49.

${ }^{167}$ Hobson, Uneasy Virtue, 50.
} 
others, including the men in the house. If public affairs were his, the world of private affairs would be hers. ${ }^{168}$

The primary strategy of female moral reformers was to change the social perception of prostitutes and who was ultimately responsible for their moral downfall. In the eighteenth century, male fornicators were punished with a fine while their female partners were whipped. By the early nineteenth century, the gender and class bias toward moral offenders that had always existed became official policy. Technically, laws were not gendered and men and women could be charged with the same crimes of lewdness. In practice, however, there existed a double standard that increased the legal disparity between the genders. In Boston, for example, men constituted roughly one-fourth of all public lewdness cases in the early years of the century, a statistic that fell to about fifteen percent by 1840 . In 1850, no men were charged with lewdness. Throughout this period, women were regularly charged with lewdness while their male counterparts went largely unpunished. ${ }^{169}$ In their effort to eliminate the double standard and persuade society to hold lascivious men accountable for their crimes, female moral reformers recast fallen women as the exploited and men as the exploiters.

An early issue of the American Female Moral Reform Society’s (AFMRS) bi-monthly periodical, the Advocate of Moral Reform (AMR), compared immoral American men to packs of mad dogs left unchecked to run the streets. Seeking to reach a Christian audience who would be horrified at society's excessive licentiousness, the $A M R$ and other moral reform publications were full of emotional allusions to the Bible. Comparing urban society to Sodom and Gomorrah, periodicals depicted profligate males as "villains," "fiends," and "fornicators." The article in the $A M R$ recognized that antagonizing the "mad pack" would likely make them "bark louder, and

\footnotetext{
${ }^{168}$ Carroll Smith-Rosenberg, "Beauty, Beast, and the Militant Woman" in Disorderly Conduct: Visions of Gender in Victorian America (New York: Alfred A. Knopf, 1985), 126.

${ }^{169}$ Hobson, Uneasy Virtue, 33-34.
} 
bite harder," but the women reformers believed this would be the way to shift public attention to the injustice of the double standard and hold men responsible for their actions. In the first issue of the $A M R$, readers were reminded: "No effort need be made to fasten disgrace upon the licentious woman; she is disgraced already, and effectually shut out from all communication with the virtuous of the other sex: but the licentious man, as guilty and polluted as the woman is still permitted to move in respectable society.", 170

The battle for morality that had been brewing throughout Stula's trial came to a head during the defense and prosecution's closing speeches. What is remarkable about the final addresses from both lawyers is the focus not on insanity, but on morality and notions of true womanhood. The winning argument from Sturla's attorney, A.S. Trude, effectively employed the rhetoric that female moral reformers had utilized decades earlier to argue that all fallen women lost their virtue at the hands of licentious men. The closing statements given by Trude and state's attorney Mills are highly significant in revealing the true nature of the Sturla trial. Officially, Trude employed a two-pronged defense of self-defense and insanity, but the overarching issue that becomes clear in the closing statements was one of morals. Prosecutor Mills reminded the jury in the initial closing remarks that for five years the couple had lived a "life of the most unholy character," and that their relationship in general was a "standing menace to public morals and a constant violation of the law." ${ }^{, 171}$ Despite this truth, Mills claimed, it was "voluntary" on the parts of Sturla and Stiles, making both parties equally responsible for their behavior.

From the beginning of the defense's closing speech, A.S. Trude echoed much of the frustrated and anger-fueled moral reform rhetoric of half a century earlier in his efforts to exonerate his client. Of course, he could not hope to convince the jury that Sturla was innocent,

\footnotetext{
${ }^{170}$ Advocate of Moral Reform, 1835, quoted in Shaver, Reforming Women, 38.

${ }^{171}$ Trial transcripts, as quoted in Turner, Sturla-Stiles Tragedy, 185.
} 
but he could endeavor to morally exonerate her by establishing Stiles as the true criminal and Sturla his victim. According to Trude, Sturla was at a disadvantage from the moment Stiles first saw her as "a fresh victim of man's lust" whose only offense "was in yielding to the strongest of all human passions under a promise of marriage made by our sex." Naturally, the defense claimed, it was Sturla's Italian heritage that predisposed her to succumbing to such passions. Italy, the "land of dreams, of poetry and romance," is a place "so near the sun" that passions are intensified to such an extent that they often culminate in death. "Italian women," Trude told the jury, "are creatures of passion and act from impulse rather than from reason, and that God made them such." As a weak, frail, Italian woman whose passions and impulses were "incident to her nativity," she could not be to blame. ${ }^{172}$ Stiles, on the other hand, had been brought up in an atmosphere of wealth, received an excellent education, and "possessed a degree of intelligence that bordered on genius." Despite his fortunate upbringing, he became a "gambler by choice" and a "libertine from inclination," "enter[ing] into a career that either ends in the penitentiary or the morgue." As libertines are wont to do, Stiles falsely claimed his love for Sturla, as he was "incapable" of that particular emotion. Instead, Trude asserted, Stiles "regarded her as a gambler would a dice box —an agent to replenish his depleted pocket." ${ }^{173}$

After this introduction and a breakdown of their two-pronged defense, court was adjourned for the night. The following day, Trude resumed his speech. This second day of closing remarks is striking because as both attorneys made their addresses, it is apparent that their main goal was less about persuading the jury whether or not the defendant was insane, nor that she acted out of self-defense or premeditated her lover's murder. Instead, the speeches made by both Trude and Mills were dominated by an argument over virtue and vice. Remarkably, the

\footnotetext{
${ }^{172}$ Trial transcripts, as quoted in Turner, Sturla-Stiles Tragedy, 187-188.

${ }^{173}$ Trial transcripts, as quoted in Turner, Sturla-Stiles Tragedy, 188.
} 
only instance in which Trude so much as mentioned Sturla's alleged insanity on the final day in court was in reference to the fact that she voluntarily maintained a relationship with a man who consistently beat her. Trude claimed this was so unnatural that the only explanation was insanity. $^{174}$

Trude framed his depiction of Sturla as the victim by explaining to the jury that she was a casualty of the immoral urban society in which they were all complicit. Such a society had given rise to the Owl Club, the fraternal organization of which Stiles was a member. Despite its founding by respectable men, Trude explained that when the organizers had retired they surrendered their membership to "a fourth-class consisting of rakes and libertines." 175 Appealing to the moral sensibilities of the court, the defense adopted a tone that sounded as if it could have been lifted from the pages of the Advocate of Moral Reform itself, claiming that members of the Owl Club and other men like them were a tremendous danger to the community and a "greater menace to society than professional criminals." ${ }^{176}$ According to Trude, all of this was due to the malformation of society itself:

“...for it visits all its venom on poor defenseless woman while her villainous betrayer treads ankle deep in the rich carpets of palatial mansions, his head unbowed in shame. The victim of his perfidy and lust, however, is exiled from society, banished from home and driven to a life of prostitution, and finally sleeps on the cold marble slab at the morgue. No woman becomes a prostitute except through the agency of our sex. Upon woman falls all the chances of exposure and shame, and she alone is made the sufferer." $" 177$

\footnotetext{
${ }^{174}$ Turner, Sturla-Stiles Tragedy, 213.

175 Trial transcripts, as quoted in Turner, Sturla-Stiles Tragedy, 214.

${ }_{177}^{176}$ Trial transcripts, as quoted in Turner, Sturla-Stiles Tragedy, 215.

${ }^{177}$ Trial transcripts, as quoted in Turner, Sturla-Stiles Tragedy, 215, italics in original.
} 
Trude went on to tell the jury that its verdict was critical, as it would be a reflection of the true morals of society. If Sturla were convicted, they would "elate the vengeful members of the Stiles family, and the Owl Club and every pimp and libertine in the city [would] rejoice." On the other hand, to acquit her would "send a thrill of joy and gladness into every home where virtue lives, and where vice may creep in to deceive and destroy." 178

The defense recognized that, at least for some members of the jury, the issues of insanity and self-defense were not nearly as straightforward as the debate over virtue and vice. Despite most expert witnesses confirming their belief that the defendant was unlikely to have been of sound mind at the time of the murder, the insanity defense was complicated by debates between physician witnesses over the existence of temporary insanity and moral insanity. To muddle the issue further, the court had reminded the jury that legal insanity was a question of law and fact and they were "not to be governed by the opinion of any medical expert." ${ }^{\text {"179 }}$ In terms of the selfdefense claim, the jury might well believe that Sturla was a victim of repeated violence, but no one witnessed exactly what happened in the hotel room or who struck first. Trude made an appeal to the all-male jury to set a moral precedent with the case. By acting as protectors of virtue, they would send a message to rakes and libertines throughout Chicago who might otherwise be inclined to take advantage of a fallen angel under the assumption that there was no law to protect prostitutes, as Stiles had previously told Sturla. Their verdict would inform those men that "they are in error - that the misfortunes of the fallen woman does not place her beyond the pale of the law." ${ }^{\prime 180}$ Trude implored the jury not to be prejudiced against the defendant on account of her nationality or surroundings, but instead to cross class lines and render a verdict

\footnotetext{
${ }^{178}$ Trial transcripts, as quoted in Turner, Sturla-Stiles Tragedy, 218.

${ }^{179}$ People of the State of Illinois versus Theresa Sturla, alias etc., (July 1882).

${ }^{180}$ Trial transcripts, as quoted in Turner, Sturla-Stiles Tragedy, 219.
} 
that would allow them to look their wives, daughters, and sweethearts in the face, knowing in their hearts that they had delivered moral justice.

The rhetoric that had once been expressed by women for an evangelical Christian audience had now been used by an attorney in Chicago to persuade a group of men that they must act as moral arbiters and set an example for society. In her examination of the AFMRS, Lisa J. Shaver defines gendering as “women's strategic use of societal gender distinctions assigned to them to garner ethos and assume power."181 To borrow her terminology, Trude's strategy of "gendering" the argument over virtue and vice might well have been the most important factor in the jury's ultimate verdict. Trude effectively used gender distinctions assigned to nineteenth century women in order to incite sympathy and exonerate his client. In order for this strategy to work, the jury would need to be convinced that Sturla was not the siren of vice that that Mills made her out to be.

Feminist scholar Sandra Lee Bartky has written that women must become aware of themselves as undeserving victims in society in order to develop a feminist consciousness. ${ }^{182} \mathrm{~A}$ century and a half before Bartky made this argument, female moral reformers developed a consciousness of victimization in order to propel their agenda. Reformers redefined traditional views of womanhood so as to stress the commonality of all women, enabling the movement to define the enemies of one class of women as the enemies of all women. With this logic, women who eventually became prostitutes had an intrinsic goodness and so could not possibly be truly evil. Trude's observation that "no woman becomes a prostitute except through the agency of our sex" is remarkably reminiscent of an early issue of the $A M R$ that asserted, "No woman ever voluntarily surrendered the blessings of a fair name. The sensitive plant shrinks not more

\footnotetext{
${ }^{181}$ Shaver, Reforming Women, 14.

${ }^{182}$ Sandra Lee Bartky, "Toward a Phenomenology of Feminist Consciousness," in Femininity and Domination: Studies of the Phenomenology of Oppression (New York: Routledge, 1990) 16-17.
} 
instinctively from the touch, than the nature of woman from defilement." ${ }^{, 183}$ These pronouncements emanated from the middle-class concept that woman's role largely arises from the purity of her spirit. By her very nature as a woman, Sturla was naturally morally superior to the man she murdered and thus innocent of her crime. ${ }^{184}$

To illustrate his client's purity, Trude reminded the jury of Frankie Weed, who had delivered one of the first testimonies they heard. Sturla met Weed three years before the trial when he was about twelve years old. Having become a "wanderer" in the wake of his father's death and mother's re-marriage, Weed was working as a newsboy and bootblack when he met Sturla. "With that attachment to children that has marked her life," Trude told the jury, "She became interested in him" and took him on as her ward, providing him with clothing and sending him to school. ${ }^{185}$ In the short time since meeting Sturla, Weed had become a "respectable farmer," "who but for this defendant would probably have been a thief." This showed, Trude argued, that "when left alone and uncontrolled by any person, [Sturla's] inclinations were in the direction of morality and purity of life, and above all, charity." ${ }^{, 166}$ Despite Sturla being a young woman who had never had children, emphasizing her "attachment to children" and care for Weed would show the jury that she possessed piety and an innate motherly instinct, pillars of true womanhood. ${ }^{187}$ Trude concluded his closing speech by reminding the jury that Christmas was approaching and asked them to recall the savior's sacred words "for imitation and example, and unite in saying to this no less unfortunate and stricken woman: "Go thou and sin no more."'

\footnotetext{
${ }^{183}$ New-York Female Moral Reform Society, Advocate of Moral Reform, Jan. 1835, 31.

${ }^{184}$ A. Cheree Carlson, "Creative Casuistry and Feminist Consciousness: The Rhetoric of Moral Reform," Quarterly Journal of Speech 78 (1992), 23.

${ }^{185}$ Trial transcripts, as quoted in Turner, Sturla-Stiles Tragedy, 199.

${ }^{186}$ Trial transcripts, as quoted in Turner, Sturla-Stiles Tragedy, 219.

${ }^{187}$ Welter, Dimity Convictions, 21-41.
} 
According to the Chicago Daily News, Trude had barely finished speaking "when the great crowd in the court-room broke into an uproar of applause." 188

Following Trude's closing speech, state's attorney L.L. Mills was given the last word. Tasked with refuting all of the defense's claims regarding Sturla's inherent virtue, Mills employed the standard courtroom technique of character assassination. ${ }^{189}$ Mills argued that much of the sentimentality expressed toward the defendant had no foundation in fact and accused the defense of magnifying her sufferings, warning the jury against "mistaken philanthropy and erroneous pity." ${ }^{, 190}$ In an attempt to prove this point, Mills asked the jury to consider whether Sturla's sufferings had been greater than any other woman endured:

"Woman is the sufferer always. That is the nature of her physical organization. She is the burden-bearer. With her tender love she bears the griefs of man and children. The woman — honest, virtuous, good, who never broke a law, who slaves from early morning till midnight hour, who lives upon scanty fare, who takes care of her boys and girls—-she is a sufferer too.",191

Like his legal adversary in this trial, Mills employed an argument that centered on justice for the proper Victorian woman. This time, though, the woman who truly suffered was not she who was on trial, but rather the mother of the deceased. Mills begged the jury to empathize with Mrs. Stiles, who had been present in court throughout the trial, forced to sit just feet away from the harlot supposedly responsible for the "miserable, hurried, brutal death of her favorite child."192 Mills attempted to leverage the sanctity of motherhood in order to garner compassion from the jury, but the prosecutor may have ultimately spoiled his own argument when he also conceded to

\footnotetext{
${ }^{188}$ Turner, Sturla-Stiles Tragedy, 220.

${ }^{189}$ Hobson, Uneasy Virtue, 73.

${ }^{190}$ Turner, Sturla-Stiles Tragedy, 224.

${ }^{191}$ Turner, Sturla-Stiles Tragedy, 225.

${ }^{192}$ Trial transcripts, as quoted in Turner, Sturla-Stiles Tragedy, 223.
} 
Stiles' libertinism. Within the bounds of true womanhood it was the responsibility of mothers to instill virtue in their children. Part of this was the expectation that mothers, not fathers, would supervise the sexual education of their sons. ${ }^{193}$ Charles Stiles' shameless escapades would indicate that Mrs. Stiles had failed in her womanly duty to raise a respectable son.

Not only were Sturla's sufferings exaggerated by her attorney, Mills claimed, but so too was the extent to which she was a victim. He saw no reason to pity the "indicted harlot," as she had voluntarily left her family in Baltimore to pursue a life of sin. Moreover, it was impossible to apply the same test of judgment to the mistress and her man as they might apply to a good man and good woman because there were "evident responsibilities, risks, dangers, perils in the relations of mistress and man that do not belong to wife and husband. She was in willing defiance of the rights of home, of morals, of law." ${ }^{194}$ Implicit in the debate over whether Sturla had been seduced or that she had lured Stiles into her web of depravity was the understanding from both sides that her sexuality made her a problem. Sturla could have been the angel she was expected to be but her sexual desire from a young age made her a fallen angel and criminal, ultimately making the defendant's sexuality a central issue in court.

The belief that prostitutes were natural murderers had existed since at least 1836, when the editor of the New York Herald, James Bennett, reported on Helen Jewett's murder. Bennett claimed it was not possible that Richard Robinson was the murderer and suggested it was more likely a woman was the killer. He wrote, "How could a young man perpetrate so brutal an act? Is it not more like the work of a woman? Are not the whole train of circumstances within the ingenuity of a female, abandoned and desperate?"195 The Jewett murder emphasizes the implication that in cases of fallen women slain, the true wickedness of the crime emanated from

\footnotetext{
${ }^{193}$ Welter, Dimity Convictions, 39; Smith-Rosenberg, "Beauty, Beast, and the Militant Woman," 119.

${ }^{194}$ Trial transcripts, as quoted in Turner, Sturla-Stiles Tragedy, 226.

${ }^{195}$ As quoted in Cohen, Murder of Helen Jewett, p. 21.
} 
the victim's sexuality. The Sturla trial demonstrates this was also true when the fallen woman was standing trial herself. Karen Halttunen discusses the Gothic phenomenon of stories of sexual murder that shifted the focus from the "male murderer as monstrous moral alien to his female victim as a monstrous sexual alien." ${ }^{, 196}$ In Sturla's case, the prosecution and defense worked together to characterize her as a moral alien and sexual alien.

In an argument directly countering the earlier claims made by the defense concerning the defendant's womanhood, Sturla had betrayed her basic domestic and religious duties as a woman and therefore did not deserve the jury's sympathy. Of course, the jury ultimately did show Sturla sympathy in the form of a manslaughter verdict that did not result in her execution, but only one year in prison. Even though she did not win a full acquittal, the jury decided the murderess had exhibited enough of the attributes expected of a respectable woman and that she deserved a chance at redemption. In reality, a murder conviction would have amounted to an admission that Sturla had succumbed to passion, therefore challenging the cultural standard of female passionlessness and its relation to moral superiority over men. In order to preserve the standard that allowed men to behave immorally with near impunity, the all male jury needed to validate the argument that Sturla's passion emanated from her ethnicity and defective reproductive organs by absolving her of the crime. As scholars have already observed, there is an abundance of historical evidence that justice for women is in the hands of men whose desire is to maintain control of the social order. The Sturla trial is one of those pieces of evidence. ${ }^{197}$

After the trial, any discussion of Sturla's sanity was virtually nonexistent. Instead, the great many reports written about her during her time in prison centered on the question of whether, upon her release, she would change her ways and live a virtuous life or if she would

\footnotetext{
${ }^{196}$ Halttunen, Murder Most Foul, 174.

197 Ann Jones, Women Who Kill (New York: The Feminist Press, 2009), 4.
} 
return to the fallen sisterhood and go back to her old life of sin and depravity. Once the verdict was read, it became clear that the public had mixed feelings regarding whether or not Sturla could or would reform. Chicago media outlets generally portrayed Sturla in a positive light, such as when a reporter from the Inter Ocean visited the prison on the Fourth of July, 1883. Sturla "was the most noticeable figure among the group" of thirty female convicts who celebrated the holiday on the prison grounds. Although she was dressed in a gingham gown like the rest of the prisoners, Sturla had "an appearance of neatness about her that was lacking with all the rest." At the request of the prison matron, Theresa sang several songs for the group and "was loudly applauded for her efforts." ${ }^{198}$

Many Chicago reporters expected that with Mrs. Black's help Sturla would find success on the stage upon her release, although some were seemingly convinced that it would be impossible for her to leave her old ways behind. One editorial argued that the "scarlet woman" intended to "put aside her well-meaning friends for old associates," which proved that "all attempts to reform such characters are useless. ${ }^{\not 199}$ Media outlets outside of the city were even more critical of the Chicago murderess. The Detroit Free Press reported that Sturla had "simulated grief, agony and despair" in order to "fool the jury," and admonished "idiot reporters" in Chicago for "gushing over murderers... and making heroes of hoodlums and brutes." ${ }^{200}$ The St. Louis Post suggested that the only reason Sturla stood out among the "thousands of her class who are allowed to go down to the gutter unnoticed and uncared for," was that she was "pretty enough to have made a newspaper sensation, and [had] rounded out a life of shame by killing her paramour in a moment of passion." The author of this particular piece chastised Chicago's idea

\footnotetext{
198 "Behind the Bars: Celebration at Joliet State Penitentiary," Chicago Daily Tribune, July 5, 1883, 2.

199 "Misdirected Efforts," Inter Ocean, Jan. 6, 1883, 12.

200 "How She Fooled the Jury," Detroit Free Press, Jan. 3, 1883, 4; “The Giddy Gusher," Detroit Free Press, June 8, 1883, 4.
} 
of philanthropy for believing members of the fallen sisterhood were entitled to sympathy if they were pretty and accused Sturla's supporters of seeking personal notoriety in aligning with her.

There are good women in St. Louis, the author wrote, "Who devote their lives to the relief of the fallen," and do not "neglect the deserving to take part in a criminal sensation.,"201

The most extensive commentary on the Sturla case was O.E. Turner's Sturla-Stiles Tragedy, published in 1883 while Sturla was still in prison. Following the trial account, Turner concluded the book with what amounts to a series of short essays discussing the various faults of society and their causes, casting the sensational events of the crime and trial as a Christian morality tale. He does not place blame on either party but rather on society itself. Turner explained that this tragedy embodies the sad truth that Chicago, "the great maelstrom of iniquity," is a society that lacks Christ's love. It is this "want of love that creates prostitutes, libertines, and paupers and...is the primal cause of all the misery of this world."202 It was the "universal lack in the moral foundation of marriage" that made crime and licentiousness so abundant. Turner also declared that upper class fathers and mothers focused so much on profit and popularity that their sons became "social egotists and domestic tyrants," while their daughters grew up with "enervated nerves and a weak will." ${ }^{, 203}$ He posited that in order to instill proper morality, every woman should be educated and trained to appreciate the "excellence and power of womanly virtue and chastity." Men needed lessons in self-purity and in being a friend and protector to women, "honoring her virtue as a woman and as the mother of his kind."204 According to Turner, Theresa Sturla embodied a woman whose craving for love compelled her actions. The "pleading aspirations of her better nature" indicated her desire to reach the "sweet

\footnotetext{
201 “The Sturla Case," St. Louis Post, Nov. 30, 1883, 4.

202 Trial transcripts, as quoted in Turner, Sturla-Stiles Tragedy, 229.

${ }^{203}$ Trial transcripts, as quoted in Turner, Sturla-Stiles Tragedy, 244.

${ }^{204}$ Trial transcripts, as quoted in Turner, Sturla-Stiles Tragedy, 250.
} 
light of the purer and better life. ${ }^{, 205}$ In the final pages of the book, Turner pondered what society could now do for Sturla, who displayed a true woman's heart "capable of the deepest devotion and self-sacrifice," showing that there was something worth redeeming. ${ }^{206}$

At the dawn of the Progressive Era, Turner was calling for a complete reformation of Chicago society. The Sturla trial occurred at a historical moment when urban society, especially in Chicago, struggled to counter vice with virtue. Vice and prostitution was so entrenched in Chicago society that the Chicago Times referred to feeble containment efforts made by the municipal government as a "co-partnership of Chicago with harlotry." ${ }^{207}$ The Chicago Daily News expressed fears that nothing could eliminate "the polluting presence of abandoned women who wandered through the streets. ${ }^{208}$ If the events of Stiles' murder had taken place just a decade or two earlier, it is less likely that the murderess would have been treated the same way by the public. For most of the century, it had been imperative to find the guilty woman in cases that involved fallen angels, even if she were the victim in the crime. By the 1880 s, however, it was clear that many Chicagoans desired dramatic changes in the social order and prostitution was a central part of the conversation.

Sturla-Stiles Tragedy could be viewed as a precursor to the much more famous book about Chicago's social problems written a decade later, If Christ Came to Chicago!, by William T. Stead. Stead first visited Chicago in October 1893, arriving on the last day of the World's Columbian Exposition. In stark contrast to the gleaming White City of the fair, Stead found himself in an American city that was struggling through an economic depression and faced the problem of widespread unemployment just before winter. After a few days in town and a visit to

\footnotetext{
${ }^{205}$ Trial transcripts, as quoted in Turner, Sturla-Stiles Tragedy, 252.

${ }^{206}$ Trial transcripts, as quoted in Turner, Sturla-Stiles Tragedy, 263.

${ }^{207}$ Quoted in Pierce, A History of Chicago Vol. III, 306.

${ }^{208}$ Quoted in Pierce, A History of Chicago Vol. III, 306.
} 
the Levee district, Stead was disturbed to find a corrupt municipal government and welfare agencies that were either unable or unwilling to manage the massive numbers of unfortunate people who needed help. But he also saw a commendable reform movement that had been in development for several decades. Shortly before his trip, Stead wrote of his admiration for Frances Willard's temperance work, predicting that Chicago might become "the centre of the English-Speaking Race, so far as Moral Reform is concerned." However, he found that the burgeoning reform movement in Chicago was impeded by internal distrust and an inability to truly unify. Stead began working with reformers and published If Christ Came to Chicago! as a provocative exposé of Chicago's corruption and underground economy in 1894, allegedly selling 70,000 copies on its publication day. ${ }^{209}$

Virtually all of the social problems addressed by Turner in Sturla-Stiles Tragedy are represented and expanded upon in Stead's book, with an appendix featuring a color-coded map of the Levee district containing precise locations of brothels, saloons, and pawnbrokers. The fight for reform, especially as it pertained to prostitution, came to a head in 1910 when the 30 member Chicago Vice Commission was formed and tasked with determining whether prostitution should be formally outlawed or remain a regulated business in segregated vice districts. In 1911, the commission published the findings of their research in a document entitled The Social Evil of Chicago. By the early twentieth century, prostitutes were often painted as innocent victims who should be viewed sympathetically. The Vice Commission lamented the plight of the prostitute:

Against these powerful business interests, the liquor dealer, the house owner and his agents, the men who run the place, the furnisher of all sorts from butcher and

\footnotetext{
${ }^{209}$ Joseph O. Baylen, “A Victorian's 'Crusade' in Chicago,” The Journal of American History 51, no. 3 (Dec. 1964), 418-434.
} 
grocer to the dry goods houses and the supported men, against these stand the girl, usually young, feeble of will, unskilled as a worker, a lover of ease, perhaps first deceived, and always after a time the victim of liquor, "dope," and other stimulants...It is obvious that the weaker factor, the girl, will be crushed in so unequal a conflict. On her falls the ignominy, the loss of health or social position and final physical and social death. While the men who profit from this vice, live on, sleek and prosperous — often so powerful in politics that even decent men dare not expose them."${ }^{210}$

While their rhetoric echoes that of earlier moral reformers, the social reformers who made up urban vice commissions were no longer the aggravated, vocal women who put together the Advocate of Moral Reform in the 1830s. Dominating the movement at the turn of the century were male reformers who saw the prostitute as a threat to the social order.

The changing attitudes toward prostitution reflect tensions brought on by rapid and dramatic changes in American society throughout the latter half of the nineteenth century, including industrialization, commercialization, and urbanization. Progressive Era Chicagoans felt threatened by challenges to Victorian morality that these changes posed and looked to prostitution as the manifestation of traditional American society's corruption. What reformers feared most was the way prostitution endangered conventional family life and values. Falling birth rates were blamed on sterility caused by venereal disease brought to the family by the evils of prostitution. The Chicago Vice Commission decreed, "A healthy woman living in wedlock all

\footnotetext{
${ }^{210}$ Chicago Vice Commission, The Social Evil in Chicago, (Chicago: American Vigilance Association, 1911), 285.
} 
of her child-bearing life, under favorable circumstances for natural procreation, should have a family of ten children."211

Reformers also blamed prostitution for the changing role of middle-class women. As prostitutes were traditionally some of the only women to enter the public arena, middle-class women who ventured outside the home for any reason blurred the line between the "lady" and prostitute. For panicked males who feared for their own place in society, prostitution signified the lawlessness of women moving into the public sphere, away from their designated roles as wife and mother. ${ }^{212}$ In a way, the prostitute came to represent the imminent downfall of traditional American society if it were not stopped. If the fallen women at the heart of the problem were not capable of redemption, then perhaps neither was Chicago society as a whole.

On its surface, the trial of Theresa Sturla was an issue of the defendant's alleged insanity, and there is no doubt that such a sensational defense aroused a great interest in the case. However, analyzing the various interpretations of Sturla's morality (or lack thereof) in and out of court reveals an unexpected truth about this case. In reality, the case was a crisis of class and morals that reflected the perceived dangers of changing social standards at the turn of the twentieth century. The morality of the defendant was fiercely debated before, during, and after the trial, and the same cannot be said for the issue of her insanity. The jury deemed her worthy of a chance at redemption, and the public watched and waited to see if the fallen woman really could move up the social ladder in the wake of committing a violent crime. Ultimately, Theresa Sturla sparked a larger discussion of the problems with society and her case became an example of the necessity for moral reformation in Chicago.

\footnotetext{
${ }^{211}$ Chicago Vice Commission, The Social Evil in Chicago, 299.

${ }^{212}$ Ruth Rosen, The Lost Sisterhood: Prostitution in America, 1900-1918, (Baltimore: Johns Hopkins University Press, 1982), 40-46; Welter, Dimity Convictions.
} 


\section{CONCLUSION}

On Christmas Day, 1882, a journalist from the Chicago Tribune visited Sturla in the county jail where she awaited her transport to the state penitentiary in Joliet, reporting, "She was in the best of humor." Sturla had been "submerged with Christmas presents," including candies, figs, flowers, illuminated cards, and stationary, along with a pile of letters showing support and sympathetic thoughts. She told the reporter about her favorite gifts: those that had come from her mother and brother. From her prison cell, Sturla said, "I feel very happy today, for I have heard from my mother. Here is her letter, and here is one from my brother. They make me lighthearted. This is the merriest Christmas I have known since I left home." Upon being asked if Stiles had ever "had [her] by intention," Sturla said that he had not and that she loved Stiles before and still loved him at that moment.

My love for that man may be a weakness, but I cannot eradicate it. I see some of the papers try to make me out cold and heartless and artificial. God knows my greatest punishment was the consequence of my love for Charlie Stiles. He would be as tender as a sweetheart to me one moment and knock me down the next. I could endure his blows, but do you know what tortured me more than anything else? It was to have him bring men [to Watson's] and then wait at the foot of the stairs until I could give him the money. That is what made me doubt his love. And yet he professed passionate regard for me and I was continually hearing from others of his remarks showing attachment for me.

To this, the reporter replied, "Your passion for that man in view of his treatment of you is something I never could understand." 213 To a contemporary observer, it is apparent that what Sturla exhibited in this interview and others is a classic example of traumatic bonding, or a

\footnotetext{
213 “Theresa Sturla," Chicago Daily Tribune, December 26, 1882, 8.
} 
strong emotional attachment between an abused person and his or her abuser, formed as a result of the cycle of violence. ${ }^{214}$ The reporter's remarks, along with other comments from witnesses and both attorneys during the trial underscore the fact that any conceptual understanding of psychological trauma was many decades away.

Theresa Sturla was released from Joliet State Penitentiary on Thanksgiving Day, 1883. The public had paid close attention to Sturla throughout her incarceration and, despite efforts on the part of prison staff to discreetly usher her back to the city, several hundred people waited at the Joliet train station to get a glimpse of the murderess whose trial had captivated audiences a year prior. The debate over Sturla's character and morality waged on. The Tribune reported: "Grave doubts have been expressed as to which course she would take-reform or return to her evil ways." 215

Chicagoans speculated greatly, waiting to see if Sturla would rejoin the demi-monde and return to Carrie Watson's, or if she would go with Mrs. Black and the estimable "Christian ladies" who expressed interest in her reformation. Instead, Sturla quietly rejoined her family at their home on South Dallas Street in Baltimore. When she arrived, "her mother wept over her... and gave her wayward child a warm welcome back again.” The Sturlas lived in a poor section of the city, and a reporter remarked that her "silks and satins and fur cloak seem[ed] very much out of place on Dallas Street." Madame Faye, operator of the brothel where Sturla worked as a teenager, allegedly offered the famous Chicago murderess her old position. Sturla turned down the proposal, telling a reporter, "I am not going back there, but I am to try to live a better life. We have got a little money and I can get along nicely here at home, though of course this

\footnotetext{
${ }^{214}$ Wendy Austin \& Mary Ann Boyd, Psychiatric \& Mental Health Nursing for Canadian Practice (Philadelphia: Wolters Kluwer, 2015), 1005.

215 “Theresa Sturlata: Her Release From the Penitentiary," Chicago Daily Tribune, November 30, 1883, 8.
} 
house is not like the ones I've lived in." The Chicago reporter was apparently suspicious of Sturla's claim, writing, "How long she will keep her good intentions remains to be seen."216 Media coverage of Sturla waned after her return to Baltimore. It was reported that, with the help of Mr. and Mrs. Black, she went to New York City in order to receive proper musical training and changed her name in an effort "not to be troubled by any of her former associates. ${ }^{217}$ According to an interview with her brother, James Sturla, Theresa received a number of offers from professional managers and would likely sign on as a client of Freddie Gebhardt, a prominent and well-connected member of the New York upper class. ${ }^{218}$ Unfortunately, Theresa Sturla is largely lost to history after this point in time and there is little that suggests she had any real success as a performer. However, she may have made it into Baltimore polite society, as indicated by a 1909 Baltimore Sun report that lists her name among several other women who were organizing philanthropic events in the city. ${ }^{219}$ Genealogical evidence suggests that Sturla married a man named Jerome Cella in 1901 and died in 1942, at the age of 81. She is buried alongside her parents at New Cathedral Cemetery in Baltimore.

The trial of Theresa Sturla was a unique moment in the history of Chicago. The public devoured the story of "a man of the world slain by a woman of the town." They soon learned, however, that this woman of the town was the true victim, having been habitually abused and mistreated by a supposedly respectable man. Because Stiles had betrayed the ideals of masculine respectability, Sturla largely gained the sympathy of the public before her trial began. The trial itself emphasizes the conflict between the Victorian medical and legal establishments, which ultimately allowed Sturla to become a sympathetic figure to the male jury, standing at the

\footnotetext{
216 “Teresa Sturlata: Her Arrival in Baltimore,” Chicago Daily Tribune, Dec. 7, 1883, 1.

217 "Sturlata: Her Musical Education," Chicago Daily Tribune, Jan. 14, 1884, 5.

218 "Amusements," Cincinnati Enquirer, Jan. 10, 1884, 8.

219 “Active for Fresh-Air Work," Baltimore Sun, Aug. 3, 1909, 6.
} 
intersection of competing discourses about crime and insanity. Finally, Sturla herself came to represent the moral crisis that would come to a head a few years later as Chicago became a center of Progressive Era reform efforts. The tragedy of Theresa Sturla illustrates that the ideal of true womanhood was not out of reach for a fallen woman, but the road to respectability for a woman like Sturla was paved in the blood of her abuser. 


\section{BIBLIOGRAPHY}

\section{Primary Sources}

“A Disgraceful Revelation.” The Daily Inter Ocean, July 12, 1882, 15.

“A Wanton's Revenge.” Chicago Daily Tribune, July 11, 1882, 3.

“Active for Fresh-Air Work.” Baltimore Sun, August 3, 1909, 6.

“Amusements.” Cincinnati Enquirer, January 10, 1884, 8.

Beck, Theodric Romeyn. Inaugural Dissertation on Insanity. New York: 1811.

Blandford, G. Fielding. Insanity and Its Treatment. Philadelphia: Henry C. Lea, 1871.

“Brutes Held By Love.” Chicago Daily Tribune, March 12, 1899, 30.

Burrows, George Man. Commentaries on Insanity. London: Underwood, 1828.

Chicago Vice Commission. The Social Evil in Chicago. Chicago: American Vigilance Association, 1911.

Christian, Charles. A Brief Treatise on the Police of the City of New York. New York: Arno Press, 1812.

The Christian Union, February 6, 1892.

Clephane, James O., ed. Official Report of the Trial of Mary Harris for the Murder of Adoniram J. Burroughs. Washington D.C.: W.H. \& O.H. Morrison, 1865.

"Faith Healing." Chicago Daily Tribune, March 13, 1886, 30.

“The Giddy Gusher.” Detroit Free Press, June 8, 1883, 4.

“The Girl's Career in Baltimore.” Chicago Daily Tribune, July 11, 1882, 3.

Gray, John P. “Trial of Mary Harris.” The American Journal of Insanity 22 (January 1866), 331360. 
Haslam, John. Considerations on the Moral Management of Insane Persons. London: R. Hunter, 1817.

"He Sowed the Wind and He Reaped the Whirlwind." Louisville Courier Journal, July 13, 1882, 5.

“How She Fooled the Jury.” Detroit Free Press, January 3, 1883, 4.

Hemstreet, William. Official Report of the Trial of Fanny Hyde, for the Murder of Geo. W. Watson. New York: J.R. McDivitt, 1872.

Maudsley, Henry. Body and Mind. London: Macmillan \& Co., 1873.

“Misdirected Efforts.” Daily Inter Ocean, January 6, 1883, 12.

“Nerved for the Verdict.” Chicago Daily Tribune, December 17, 1882, 6.

New-York Female Moral Reform Society, Advocate of Moral Reform. January 1835.

“Palmer House Tragedy.” Chicago Daily Tribune, July 16, 1882, 4.

Pinel, Philippe. A Treatise on Insanity. Trans. D.D. Davis. London: 1806.

Prichard, James Cowles. A Treatise on Insanity and Other Disorders Affecting the Mind. London: 1835.

Ray, Isaac. A Treatise on the Medical Jurisprudence of Insanity. Boston: Little, Brown and Company, 1853.

- "The Insanity of Women Produced by Seduction or Desertion." The American Journal of Insanity 23 (October 1866), 263-274.

Rowe, George Robert. On Some of the Most Important Disorders of Women. London: John Churchill, 1844.

Rush, Benjamin. Medical Inquiries and Observations upon the Diseases of the Mind, $2^{\text {nd }}$ ed. Philadelphia: 1818.

“She Killed Her Man.” Daily Arkansas Gazette, July 11, 1882, 4. 
Smith, Heywood. Dysmenorrhea: Its Pathology and Treatment. London: J. \& A. Churchill, New Burlington Street, 1881.

Stead, William T. If Christ Came to Chicago! London: Review of Reviews, 1894.

“The Stiles Murder Case.” New York Times, December 10, 1882, 3.

“The Sturla Case.” St. Louis Post, November 30, 1883, 3.

“Sturlata: Her Musical Education.” Chicago Daily Tribune, December 7, 1883, 5.

“Teresa Sturlata.” Chicago Daily Tribune, December 7, 1883, 1.

“Theresa Sturla.” Chicago Daily Tribune, December 26, 1882, 1.

“Theresa Sturlata: Her Release From the Penitentiary.” Chicago Daily Tribune, November 30, $1882,8$.

Tilt, Edward. The Change of Life in Health and Disease, $4^{\text {th }}$ ed. New York: Bermingham \& Co., 1882.

“Tried for Her Life.” Milwaukee Journal Sentinel, December 17, 1882, 7.

Turner, O.E. Sturla-Stiles Tragedy. Chicago: O.E. Hammond, 1883.

"The Verdict in the Mary Harris Trial." The New York Times, July 20, 1865, 4.

“The Wages of Sin.” The Daily Inter Ocean, July 11, 1882, 5.

Wardlaw, Ralph. Lectures on Magdalenism. New York: J.S. Redfield Clinton Hall, 1843.

Wynter, Andrew. The Borderlands of Insanity. London: Robert Hardwicke, 1875.

\section{Secondary Sources}

Adler, Jeffrey S. "'I loved Joe, but I had to Shoot Him': Homicide by Women in Turn-of-theCentury Chicago." The Journal of Criminal Law and Criminology (1973-) 92, no. 3/4 (Spring-Summer 2002): 867-898. 
—. First in Violence, Deepest in Dirt: Homicide in Chicago, 1875-1920. Cambridge: Harvard University Press, 2006.

Austin, Wendy \& Mary Ann Boyd. Psychiatric \& Mental Health Nursing for Canadian Practice. Philadelphia: Wolters Kluwer, 2015.

Bakken, Gorden Morris \& Brenda Farrington. Women Who Kill Men: California Courts, Gender, and the Press. Lincoln: University of Nebraska Press, 2009.

Barker-Benfield, G.J. The Horrors of the Half-Known Life: Male Attitudes Toward Women and Sexuality in Nineteenth-Century America. New York: Harper \& Row, 1976.

Bartky, Sandra Lee. "Toward a Phenomenology of Feminist Consciousness," in Femininity and Domination: Studies of the Phenomenology of Oppression. New York: Routledge, 1990.

Baylen, Joseph O. "A Victorian's “Crusade” in Chicago, 1893-1894." The Journal of American History 51, no. 3 (December 1964): 418-434.

Berg, Barbara J. The Remembered Gate: Origins of American Feminism, The Woman and the City, 1800-1860. New York: Oxford University Press, 1978.

Boyer, Jodie. “'Moral Insanity,' and Psychology in Nineteenth-Century America." Religion and American Culture: A Journal of Interpretation 24, no. 1 (Winter 2014): 70-99.

Boyle, Rachel. "She Shot Him Dead: The Criminalization of Women and the Struggle Over Social Order in Chicago, 1871-1919." PhD diss., Loyola University Chicago, 2017.

Braun, Gretchen. “'Untarnished Purity”: Ethics, Agency, and the Victorian Fallen Woman.” Women's Studies 44 (2015): 342-367.

Carlson, A. Cheree. The Crimes of Womanhood: Defining Femininity in a Court of Law. Urbana: University of Illinois Press, 2009.

_. "Creative Casuistry and Feminist Consciousness: The Rhetoric of Moral Reform." Quarterly Journal of Speech 78 (1992): 16-32.

Clement, Elizabeth Alice. Love For Sale: Courting, Treating, and Prostitution in New York City, 1900-1945. Chapel Hill: The University of North Carolina Press, 2006. 
Cohen, Patricia Cline. The Murder of Helen Jewett: The Life and Death of a Prostitute in Nineteenth-Century New York. New York: Alfred A. Knopf, 1998.

Colaizzi, Janet. Homicidal Insanity, 1800-1985. Tuscaloosa: University of Alabama Press, 1989.

Cott, Nancy F. The Bonds of Womanhood: “Woman's Sphere” in New England, 1780-1835. New Haven: Yale University Press, 1977.

Covey, Russell D. "Temporary Insanity: The Strange Life and Times of the Perfect Defense." Boston University Law Review 91, (2011): 1597-1668.

D'Emilio, John \& Estelle B. Freedman. Intimate Matters: A History of Sexuality in America. Chicago: University of Chicago Press, 1988.

Freedman, Estelle B. "Sexuality in Nineteenth-Century America: Behavior, Ideology, and Politics." Reviews in American History 10, no. 4 (December 1982): 196-215.

Fox, Vivian C. "Historical Perspectives on Violence Against Women." Journal of International Women's Studies 4, no. 1 (November 2002): 15-34.

Gamber, Wendy. “'The Notorious Mrs. Clem': Gender, Class, and Criminality in Gilded Age America." The Journal of the Gilded Age and Progressive Era 11, no. 3 (July 2012): 313343.

Gilfoyle, Timothy J. City of Eros: New York City, Prostitution, and the Commercialization of Sex, 1790-1920. New York: W.W. Norton \& Company, 1992.

_. "Archaeologists in the Brothel: "Sin City," Historical Archaeology and Prostitution." Historical Archaeology 39, no. 1 (2005): 133-141.

Glenn, Myra C. "Wife-Beating: The Darker Side of Victorian Domesticity." Canadian Review of American Studies 15, no. 1 (Spring 1984): 17-33.

Haber, Carole. The Trials of Laura Fair: Sex, Murder, and Insanity in the Victorian West. Chapel Hill: The University of North Carolina Press, 2013.

Halttunen, Karen. Confidence Men and Painted Women: A Study of Middle-class Culture in America, 1830-1870. New Haven: Yale University Press, 1982. 
_. "Early American Murder Narratives: The Birth of Horror." In The Power of Culture: Critical Essays in American History, edited by Richard Wightman Fox \& T.J. Jackson Lears, 67-101. Chicago: University of Chicago Press, 1993.

—. Murder Most Foul: The Killer and the American Gothic Imagination. Cambridge: Harvard University Press, 1998.

Hartman, Mary S. Victorian Murderesses: A True History of Thirteen Respectable French and English Women Accused of Unspeakable Crimes. New York: Schocken Books, 1977.

Hartog, Hendrik. "Lawyering, Husbands' Rights, and "the Unwritten Law" in NineteenthCentury America." The Journal of American History 84, no. 1 (June 1997): 67-96.

Heinzelman, Susan Sage \& Zipporah Batshaw Wiseman. Representing Women: Law, Literature, and Feminism. Durham: Duke University Press, 1994.

Herbert, T. Walter. Dearest Beloved: The Hawthornes and the Making of the Middle-Class Family. Berkely: University of California Press, 1993.

Hobson, Barbara Meil. Uneasy Virtue: The Politics of Prostitution and the American Reform Tradition. New York: Basic Books, 1987.

Hughes, John Starrett. In the Law's Darkness: Isaac Ray and the Medical Jurisprudence of Insanity in Nineteenth-Century America. New York: Oceana Publications, 1986.

Ireland, Robert M. "Frenzied and Fallen Females: Women and Sexual Dishonor in the Nineteenth-Century United States." Journal of Women's History 3, no. 3 (Winter 1992): 95-117.

_. "Insanity and the Unwritten Law." The American Journal of Legal History 32, no. 2 (April 1988): 157-172.

_. "The Libertine Must Die: Sexual Dishonor and the Unwritten Law in the NineteenthCentury United States." Journal of Social History 23, no. 1 (Autumn 1989): 27-44.

Jacobson, Matthew Frye. Whiteness of a Different Color: European Immigrants and the Alchemy of Race. Cambridge: Harvard University Press, 1998.

Jacoby, Susan. Wild Justice: The Evolution of Revenge. New York: Harper \& Row, 1983.

Jones, Ann. Women Who Kill. New York: The Feminist Press, 2009. 
Kerber, Linda K. “ Separate Spheres, Female Worlds, Woman's Place: The Rhetoric of Women's History." The Journal of American History 75, no. 1 (June 1988): 9-39.

Kohrs Campbell, Karlyn. Man Cannot Speak For Her: A Critical Study of Early Feminist Rhetoric. New York: Praeger Publishers, 1989.

Lander, Louise. Images of Bleeding: Menstruation as Ideology. New York: Orlando Press, 1988.

Lears, T.J. Jackson. Something For Nothing: Luck in America. New York: Viking, 2003.

Lefkowitz Horowitz, Helen. Rereading Sex: Battles over Sexual Knowledge and Suppression in Nineteenth-Century America. New York: Alfred A. Knopf, 2002.

Linders, Annulla \& Alana Van Gundy-Yoder. "Gall, Gallantry, and the Gallows: Capital Punishment and the Social Construction of Gender, 1840-1920." Gender and Society 22, no. 3 (June 2008), 324-348.

Lystra, Karen. Searching the Heart: Women, Men, and Romantic Love in Nineteenth-Century America. New York: Oxford University Press, 1989.

Mason, Michael. The Making of Victorian Sexuality. Oxford: Oxford University Press, 1994.

Meyerowitz, Joanne J. Women Adrift: Independent Wage Earners in Chicago, 1880-1930. Chicago: The University of Chicago Press, 1988.

Mill, John Stuart \& Harriet Taylor Mill, edited by Alice S. Rossi. Essays on Sex Equality. Chicago: University of Chicago Press, 1970.

Parson, Elaine Frantz. Manhood Lost: Fallen Drunkards and Redeeming Women in the Nineteenth-Century United States. Baltimore: Johns Hopkins University Press, 2003.

Peiss, Kathy, ed. Major Problems in the History of American Sexuality. Boston: Houghton Mifflin Company, 2002.

Peterson, David. "Wife Beating: An American Tradition." The Journal of Interdisciplinary History 23, no. 1 (Summer 1992): 97-118.

Pierce, Bessie Louise. A History of Chicago, Vol. III: The Rise of a Modern City, 1871-1893. New York: Alfred A. Knopf, 1957. 
Roberts, Mary Louise. “True Womanhood Revisited,” Journal of Women's History 14, no. 1 (Spring 2002): 150-155.

Robertson, Darrel M. The Chicago Revival: Society and Revivalism in a Nineteenth-Century City. Metuchen: The Scarecrow Press, Inc., 1989.

Roediger, David R. Working Toward Whiteness: How America's Immigrants Became White. New York: Basic Books, 2005.

Rosen, Ruth. The Lost Sisterhood: Prostitution in America, 1900-1918. Baltimore: Johns Hopkins University Press, 1982.

Rosenberg, Charles E. No Other Gods: On Science and American Social Thought. Baltimore: Johns Hopkins University Press, 1961.

- The Trial of the Assassin Guiteau: Psychiatry and Law in the Gilded Age. Chicago: University of Chicago Press, 1968.

—. "Sexuality, Class and Role in $19^{\text {th }}$-Century America." American Quarterly 25, no. 2 (May 1973): 131-153.

Rotundo, E. Anthony. American Manhood: Transformations in Masculinity from the Revolution to the Modern Era. New York: BasicBooks, 1993.

Russett, Cynthia Eagle. Sexual Science: The Victorian Construction of Womanhood. London: Harvard University Press, 1989.

Sachsman, David B. After the War: The Press in a Changing America, 1865-1900. New York: Taylor \& Francis, 2017.

Schuetz, Janice. The Logic of Women on Trial: Case Studies of Popular American Trials. Carbondale: Southern Illinois University Press, 1994.

Scott, Joan W. "Gender: A Useful Category of Historical Analysis.” The American Historical Review 91, no. 5 (December 1986): 1053-1075.

Severson, Nicolette. "Devils Would Blush to Look": Brothel Visits of the New York Female Moral Reform Society, 1835 and 1836." Journal of the History of Sexuality 23, no. 2 (May 2014): 226-246. 
Shaver, Lisa J. Reforming Women: The Rhetorical Tactics of the American Female Moral Reform Society, 1834-1854. Pittsburgh: University of Pittsburgh Press, 2018.

—_."'Serpents," "Fiends," and "Libertines": Inscribing an Evangelical Rhetoric of Rage in the “Advocate of Moral Reform.” Rhetoric Review 30, no. 1 (2011): 1-18.

Small, Helen. Love's Madness: Medicine, the Novel, and Female Insanity. Oxford: Clarendon Press, 1996.

Smith-Rosenberg, Carroll. Disorderly Conduct: Visions of Gender in Victorian America. New York: Alfred A. Knopf, 1985.

Spiegel, Allen D. \& Merrill S. Spiegel. "Not Guilty of Murder By Reason of Paroxysmal Insanity: The "Mad" Doctor vs. "Common-Sense" Doctors in an 1865 Trial." Psychiatric Quarterly 62, no. 1 (Spring 1991): 51-66

Srebnick, Amy Gilman. The Mysterious Death of Mary Rogers: Sex and Culture in NineteenthCentury New York. New York: Oxford University Press, 1995.

Theriot, Nancy M. “Women’s Voices in Nineteenth-Century Medical Discourse: A Step Toward Deconstructing Science.” Signs 19, no. 1 (Autumn 1993): 1-31.

Vicinus, Martha, ed. Suffer and Be Still: Women in the Victorian Age. Bloomington: Indiana University Press, 1972.

Walter, Madaline Reeder. 'Insanity, Rhetoric, and Women: Nineteenth-Century Women's Asylum Narratives.” PhD diss., University of Missouri-Kansas City, 2011.

Welter, Barbara. “The Cult of True Womanhood: 1820-1860,” American Quarterly 18, no. 2 (Summer 1966): 151-174.

—. Dimity Convictions: The American Woman in the Nineteenth Century. Athens: Ohio University Press, 1976. 